Quaternary International

January 2015, Volume 357, Pages 295-313

http://dx.doi.org/10.1016/i.quaint.2014.11.038

http://archimer.ifremer.fr/doc/00245/35648/

(c) 2014 Elsevier Ltd and INQUA. All rights reserved.

\title{
Levantine intermediate water hydrodynamic and bottom water ventilation in the northern Tyrrhenian Sea over the past 56,000 years: New insights from benthic foraminifera and ostracods
}

\author{
Angue Minto'o C.M. ${ }^{1,{ }^{*}}$, Bassetti M.A. ${ }^{1}$, Morigi C. ${ }^{2,3}$, Ducassou E. ${ }^{4}$, Toucanne Samuel ${ }^{5}$, \\ Jouet Gwenael ${ }^{5}$, Mulder T. ${ }^{2}$
}

${ }^{1}$ Université de Perpignan Via Domitia, CEFREM, UMR 5110, 52 Avenue Paul Alduy, 66860 Perpignan, France

${ }^{2}$ Geological Survey of Denmark and Greenland, Department of Stratigraphy, Copenhagen, Denmark

${ }^{3}$ Università di Pisa, Dipartimento di Scienze della Terra, Italy

${ }^{4}$ Université de Bordeaux, UMR 5805 EPOC, Avenue des Facultés, 33405 Talence cedex, France

${ }^{5}$ IFREMER-Centre Bretagne, Laboratoire Environnements Sédimentaires, F-29280 Plouzané, France

*Corresponding author : C.M. Angue Minto'o, email address : charlie.angue-mintoo@univ-perp.fr

\begin{abstract}
:
Foraminifera and ostracods have been quantitatively studied in core MD01-2472, from the upper continental slope (at water depth of $501 \mathrm{~m}$ ), to evaluate their relationship with bottom water condition variability and decipher the control of the Levantine Intermediate Water (LIW) current on benthic faunas. The occurrence of reworked ostracod species (originating from the continental shelf) and, the presence of shallow water Elphidium/Ammonia benthic foraminifera are used to estimate the degree of alongslope transport at the core site. This has revealed two intervals of along-slope transport also associated with coarse-grained contourite deposits, deposited during the YD and HS2 episodes. Planktonic-benthic foraminiferal and ostracod assemblages reflect climate oscillations. Peaks of the polar planktonic Neogloboquadrina pachyderma (left-coiling S) may be used to identify Heinrich Events. Interstadials are marked by abundant ostracod species such as Paracypris sp., Argilloecia acuminata, and Cytheropteron alatum and the presence of benthic foraminifera like Bulimina marginata, Bulimina costata and Gyroidina altiformis. The B-A and Holocene are characterized by abundant warm water species of planktonic foraminifera and by the ostracod species Polycope sp. We hypothesize that there is relationship between LIW intensification during cold rapid climate events and benthic fauna assemblage variations due to changes in: 1) bottom water ventilation; and 2) the export of nutrients and/or sediment particles by bottom currents.
\end{abstract}

Keywords : Ostracods, Foraminifera, LIW, Corsica margin 


\section{Introduction}

The last glacial period $(71,000-14,000$ y BP) was marked by climate instability

42 (Bond et al., 1992; Bond et al., 1993; Dansgaard et al., 1993), and by the millennial-scale alternations of cold (stadial) and warm (interstadial) periods, especially during Marine Isotope Stage (MIS) 3 (57,000 - 29,000 y BP) and MIS 2 (29,000 - 14,000 y BP) when the Dansgaard-Oeschger (DO) cycles occurred (Dansgaard et al., 1993; Meese et al., 1997). This sub-orbital climatic variability suggests the rapid coupling of atmospheric-oceanic systems. Previous studies have demonstrated that these rapid climatic oscillations are recorded in continental and marine records in the northern hemisphere, from Asia (Wang and Sarnthein, 1999) to Europe (Sánchez Goñi et al., 2000; Fletcher and Sánchez Goñi, 2008). In the Mediterranean Sea, these millennial-scale cycles induced rapid changes in oceanographic conditions since the sea surface temperature oscillations acted on thermohaline circulation. The link between atmospheric and marine processes has been described by several authors (Sierro et al., 1999; Cacho et al., 2002; Moreno et al., 2005; Cacho et al., 2006; Frigola et al., 2008; Sierro et al., 2009), illustrating how deep-water circulation (i.e. Western Mediterranean Deep Water, WMDW) in the western Mediterranean Sea was very active during DO stadials and Heinrich stadials (HS), and slowed down during interstadials. Similarly, in the Tyrrhenian Sea, Toucanne et al. (2012) have shown, based on sedimentological evidence (sortable silt particle-size data), that during the last glacial period the Levantine Intermediate Water (LIW) variability was strongly forced by climate variability at both Milankovitch and millennial timescales. In the North Atlantic ocean, the strengthening of the Mediterranean Outflow Water (MOW) in the Gulf of Cadiz during northern hemisphere coolings (e.g. during DO stadials and the Younger Dryas, YD, ca 12,000 y BP) is clearly recorded in the contourite deposits (Voelker et al., 2006; Toucanne et al., 2007). These studies confirm the important control of climate forcing on Atlantic-Mediterranean water exchanges on the geological timescale, in addition to North Atlantic hydrology (Rogerson et al., 2012), and LIW, which constitutes up to $80 \%$ of the Mediterranean outflow volume (Bryden and Stommel, 1984; Kinder and Parrilla, 1987; Baringer and Price, 1999).

Planktonic foraminifera are the most common source of paleoceanographic proxies, based on fossil assemblages and/or geochemical deta $(\mathrm{O}$ and $\mathrm{C}$ stable isotopes ratio in this work) and are widely used in the Mediterranean (Pérez-Folgado et al., 2003, 2004; Sierro et al., 2009). Benthic microfossils such as foraminifera and ostracods are also good paleoceanographic tools allowing reconstruction of the physical-chemical parameters such as 
1999; Morigi et al., 2001; Gooday, 2003; Schmiedl et al., 2004; Morigi et al., 2005; Fontanier et al., 2008; Alvarez Zarikian et al., 2009; Bassetti et al., 2010; Schmiedl et al., 2010).

The Western Mediterranean is presently characterized by well-oxygenated and oligotrophic conditions, with an organic carbon flux exported to the sea floor that decreases eastwards (Béthoux et al., 1998). The benthic microfaunal distribution is controlled by the carbon flux reaching the sea floor, which depends not only by the surface productivity but also on the intensity of the hydrosedimentary processes that allow the integration of consumable organic matter into the sediment (De Rijk et al., 2000).

At a regional Mediterranean scale, modern benthic foraminiferal distribution is characterized by low diversity deep-water assemblages dominated by species such as Glomospira charoides, Gyroidina orbicularis, Gyroidina altiformis, Robertinoides translucens, Biloculinella spp., Anomalinoides minimus, Trochammina inflata and Rotamorphina involuta (De Stigter et al., 1998; De Rijk et al., 1999). Nevertheless, species characterizing a low food environment like $G$. charoides and G. orbicularis are more abundant in eastern part than the western. The shelf assemblage is more diverse-and consists mainly of Ammonia beccarii, Elphidium lidoense, Elphidium granosum, Textularia pseudogramen, Textularia sagittula, Bolivina spathulata, Bolivina dilatata, Cassidulina crassa, Cassidulina levigata/carinata, Haplophragmoides membranaceum, Gavelinopsis praegeri, Bigenerina nodosaria, Trifarina angulosa and Bulimina marginata (De Rijk et al., 1999; Mojtahid et al., 2009; Milker and Schmiedl, 2012).

The taxonomy of Mediterranean Sea ostracods is well known from previous studies (Bonaduce et al., 1975; Peypouquet and Nachite, 1984; El Hmaidi et al., 1998, 1999, 2010) and their sensitivity to physical and chemical parameters (i.e. salinity, dissolved oxygen, and temperature) allows climate reconstruction on glacial-interglacial timescales, and short-term periods of environmental change (Ciampo, 2004; Bassetti et al., 2010). In modern ostracod assemblages from the Western Mediterranean, the genera Argilloecia, Krithe, Bythocypris, Henryowella and Cytheropteron dominate settings deeper than $200 \mathrm{~m}$ (Peypouquet and Nachite, 1984; El Hmaidi et al., 1999, 2010). Deep-water assemblages often contain reworked fauna from the continental shelf. In fact, allochthonous ostracods are common in deep-water assemblages (Peypouquet, 1979; Peypouquet and Nachite, 1984; Passlow, 1994; Zhou and Zhao, 1999; El Hmaidi et al., 2010) and can be used as an indicator of the intensity of downslope sediment transport (Passlow, 1994).

In this work we use foraminifera and ostracods to interpret the relationship between bottom hydrodynamic conditions, water mass ventilation and benthic microfossil assemblages 
in the Corsica Trough (northern Tyrrhenian Sea) over the last 56,000 years. We use benthic 109 microfossils as "bio-indicators" of changing environmental conditions (bottom water 110 oxygenation and organic matter flux and downslope sediment transport), which can be related 111 to variability of the intensity of circulation (Harloff and Mackensen 1997; Schmiedl and 112 Mackensen, 1997; Schmiedl et al., 1997), complimenting sedimentological analyses. We use 113 allochthonous ostracods and foraminifera to estimate alongslope sediment transfer from the 114 continental shelf and slope, and its relationship to contour current speed intensity. This 115 method is considered to enhance facies analyses of fine-grained contourites where primarily 116 sedimentary structures are difficult to distinguish and/or to interpret because they might be 117 either highly modified by bioturbation or even absent. It has previously been used to 118 recognize ice rafted debris (HS) and tsunamites (Smedile et al., 2011). Using these analyses, 119 we establish the link between the intensification of LIW and cold climate events.

\section{Geologic and oceanographic setting}

The Corsica Trough is in the eastern part of the Western Mediterranean Sea (northern Tyrrhenian sea) and is a narrow (10-30 km at the $200 \mathrm{~m}$ isobath) and shallow (430 to ca 900 $\mathrm{m}$ from the Corsica Channel to the Golo Basin) north-south trending basin, separating the Corsica Shelf from the Tuscany-Elba Shelf and Pianosa Ridge. The east Corsican margin, where core MD01-2472 was retrieved, is a continental shelf region varying from 5 to $10 \mathrm{~km}$ in width in the northern part to $25 \mathrm{~km}$ in the south, with a steep continental slope incised by numerous canyons at its margin (Fig. 1). The latter drains several small, steep mountain rivers (the Golo River being the longest with a length of $90 \mathrm{~km}$ ) that transport mainly coarse-grained material toward the deep part of the basin (Calvès et al., 2012).

Hydrographically, the Western Mediterranean is characterized by three main water masses: the surficial Atlantic Water (AW, down to $200 \mathrm{~m}$ water depth), entering through the

133 Strait of Gibraltar and flowing eastwards; the LIW (from 200 to 600 - $1000 \mathrm{~m}$ water depth)

134 formed in the Levantine Basin (Eastern Mediterranean); and the WMDW (below 600 - 1000 $135 \mathrm{~m}$ water depth) generated in the Gulf of Lions. The LIW enters into the Tyrrhenian Sea 136 through the Strait of Sicily where the Coriolis Force deflects it to the east towards the Western 137 Italian margin and then into the Corsica Trough with a northwards component. The LIW 138 shows strong seasonal oscillations and its flow is maximal during winter and early spring. 139 Measurements of modern LIW velocities in the Corsica Trough show that the LIW reaches 0$14010 \mathrm{~cm} / \mathrm{s}$ in summer and autumn, and 10-40 cm/s in winter and spring (Astraldi and Gasparini, 141 1992; Vignudelli et al., 2000). This seasonal flow velocity is driven by enhanced LIW 
142 production in the Levantine Basin, and export to the Western Mediterranean (from the 143 Ligurian-Provencal Basin to the Strait of Gibraltar) during wintertime (La Violette, 1994; Wu 144 and Haines, 1996; Millot, 1999; Pinardi and Masetti, 2000). The lowering of the Ligurian145 Provençal Basin steric level induced by winter heat losses and evaporation during the periodic 146 intrusions of cold and dry northerly winds in the Gulf of Lions (i.e. Mistral, Tramontana) also 147 play a major role in the seasonal change in LIW flow velocity in the Corsica Trough (Astraldi 148 and Gasparini, 1992, 1994; Vignudelli et al., 2000).

\section{Materials and methods}

The sediments analysed are from core MD01-2472 $\left(42^{\circ} 36.42 \mathrm{~N}, 009^{\circ} 43.97 \mathrm{E} ; 29.1\right.$ metres long), which was collected at $501 \mathrm{~m}$ water depth on the continental slope of the east

153 Corsica margin during the MD124-GEOSCIENCES 2 cruise (2001) on board the R/V Marion 154 Dufresne II (Fig. 1). Only the uppermost $12 \mathrm{~m}$ of core MD01-2472 have been studied here.

\subsection{Chronostratigraphy}

The chronostratigraphic framework of core MD01-2472 is based on $\delta^{18} \mathrm{O}$ isotopes, AMS ${ }^{14} \mathrm{C}$ dates and $\mathrm{Ca}$ intensities derived from high-resolution XRF scanning (Toucanne et al., 2012). Five additional AMS ${ }^{14} \mathrm{C}$ dates were included in the present study (see Table 1 for details). The age dates were corrected for a marine reservoir effect of $400 \mathrm{y}$, except for those from the period 15,000 - 17,000 y BP for which a correction of $800 \mathrm{y}$ was applied (cf. Siani et al., 2001). Radiocarbon ages were calibrated to calendar years using CALIB 6.0.1 and the IntCal09 calibration curve (Reimer et al., 2009).

\subsection{Lithological analyses}

Magnetic susceptibility data of core MD01-2472 were measured on non-opened core sections at $2 \mathrm{~cm}$ intervals using a Geotek Multi-Sensor Core Logger (MSCL). These data were used for identifying lithologic changes at the centimetre scale.

Grain-size analyses were performed at $5 \mathrm{~cm}$ intervals (up to $0.5 \mathrm{~cm}$ intervals in coarser sequences) on a Malvern laser microgranulometer for a high resolution facies study with no chemical pre-treatment of the bulk sediment. We used both the medium grain size (D50), which is directly represented in the lithologic log, as well as the sortable silt mean size (SS), i.e. the mean of the $10-63 \mu \mathrm{m}$ grain-size range of McCave et al. (1995), as an index of bottom flow speed (McCave and Hall, 2006). The high-resolution grain-size analyses $(0.5 \mathrm{~cm}$ interval) presented in this paper were carried out on two coarse-grained intervals $(2.45-2.55 \mathrm{~m}$ 
and 5.3-5.4 m) to constrain sedimentary facies. The SS curve is obtained by measuring 10-63

$177 \mu \mathrm{m}$ percentages with a $5 \mathrm{~cm}$ step, which represents a higher resolution than published in

178 Toucanne et al. (2012).

179 X-ray analyses were obtained with a SCOPIX image-processing tool. This tool is very useful 180 to identify internal sedimentary structures within single beds and to select samples for 181 sedimentological and paleoceanographical studies (Migeon et al., 1999). Five thin-sections 182 (10 cm long) of impregnated sediments selected from well-preserved and representative 183 sedimentary facies (see Zaragosi et al. (2006), for details) were also analysed in order to 184 interpret sedimentary processes at site MD01-2472. Microscopic observations were made 185 using a fully automated Leica ${ }^{\mathrm{TM}}$ DM6000B Digital Microscope.

\subsection{Micropaleontological and geochemical analyses}

The sediment core was sampled at $10 \mathrm{~cm}$ intervals. The bulk sediment was washed through a $63 \mu \mathrm{m}$ sieve and dried in an oven at $40^{\circ} \mathrm{C}$. The analyses of benthic and planktonic foraminifera and ostracods were carried out under a binocular microscope on the $>150 \mu \mathrm{m}$ fraction. Microfossil counting was performed on 102 samples, and relative abundances calculated for each species. All ostracod specimens were handpicked. At least 300 specimens of benthic and planktonic foraminiferal were counted.

Among planktonic foraminifera, we use Turborotalia quinqueloba, Neogloboquadrina pachyderma left-coiling (S) as cold water indicators and an assemblage with Globigerinoides ruber alba and rosea, Globigerinoides sacculifer (including Globigerinoides trilobus), Globigerinoides tenellus, Globigerinella aequilateralis, Orbulina universa to indicate warm water (Bé and Tolderlund, 1971; Blanc et al., 1975; Bé and Hutson, 1977; Hayes et al., 1999).

All benthic foraminiferal taxa were identified and counted in each sample. We interpret the abundance of Elphidium spp. and Ammonia sp. (benthic foraminifera), typical of shallow-water, as indicators of reworked sediment from the inner shelf. In order to estimate in oxygen content variation, we used the benthic foraminifera assemblage following the method proposed by Schmiedl et al. (2003) using the following formula: $(\mathrm{OH} /(\mathrm{OH}+\mathrm{LO})+\mathrm{Div}) \times 0.5$, with $\mathrm{OH}=$ relative abundance of high oxygen indicators (Pyrgo murrhina, Pyrgo sp., Triloculina sp., Sigmoilopsis schlumbergeri, Massilina secans, Cibicidoides pachyderma,

206 Cibicidoides wuellerstorfi, Cibicidoides sp., Planulina ariminensis, Quiqueloculina sp., 207 Cycloforina contorta, Biloculinella globula, Miliolinella sp.), LO = relative abundance of low 208 oxygen indicators (Cassidulinoides bradyi, Fursenkoina tenuis, Bulimina costata, Globobulimina affinis, Chilostomella sp.) and Div = normalized benthic foraminifera 
210 diversity. Diversities were normalized relative to the maximum $H(S)$ value. Finally, the term 211 was multiplied by 0.5 in order to distinguish between anoxic (minimum value $=0$ ) and oxic 212 (maximum value $=1$ ) conditions.

213 Two groups were identified among ostracod assemblages: the autochthonous and 214 allochthonous. Allochthonous elements were characterized by adding the abundance of 215 species living on the continental shelf (Pontocythere elongata, Heterocythereis albomaculata, 216 Xestoleberis sp., Paradoxostoma sp., Semicytherura sp., Loxoconcha levis, Carinocythereis 217 sp., Hemicytherura videns, Hiltermanicythere turbida, Pseudocytherura calcarata, Costa sp., 218 Aurila sp., Callistocythere sp.) (Bonaduce et al., 1975; Carbonel, 1980; Ruiz et al., 1997; 219 Hajjaji et al., 1998; Abad et al., 2005; El Hmaidi et al., 2010; Nachite et al., 2010). The 220 autochthonous group is represented by the upper neritic and bathyal species, considered as in 221 situ and not affected by transport.

222 R-mode Hierarchical Cluster Analysis was performed on the data set, using the PAST 223 (PALeontology STatistic) Program of Hammer et al. (2001). We used Ward's distance matrix 224 for ostracod and benthic foraminifera species. Of the 77 species of benthic foraminiferal and 22551 ostracods species (see appendices A and B) identified, only 17 benthic foraminiferal 226 species and 19 ostracod species (which accounted for more than 5\% of the assemblage in at 227 least one sample) were retained in this cluster analysis. The Shannon diversity index $H(S)$ was 228 also determined by PAST software.

Stable isotope (O and C) measurements were carried out on core MD01-2472 with an average time resolution of ca. $500 \mathrm{y}$ over the records (Toucanne et al., 2012). Analyses were performed using 3 to 10 specimens of planktonic foraminifera Globigerina bulloides and shallow infauna benthic foraminifera Uvigerina peregrina from the $>150 \mu \mathrm{m}$ size fraction.

233 The low abundance of Uvigerina peregrina in the uppermost $2 \mathrm{~m}$ of the core (i.e. interglacial 234 deposits) prevented measurements of stable isotopes for this species. As a result, Uvigerina 235 mediterranea was used to replace Uvigerina peregrina for the upper part of core MD01-2472. 236 Isotope analyses were conducted at the University of Bordeaux (UMR CNRS 5805 EPOC) 237 using an Optima Micromass. The external reproducibility for standards on this mass 238 spectrometer is $\pm 0.03 \%$ o ( 1 sigma) per mil for $\delta^{13} \mathrm{C}$ measurements, and $\pm 0.03 \%$ ( 1 sigma) 239 per mil for $\delta^{18} \mathrm{O}$ measurements. A correction factor of $-0.25 \%$ for $\delta^{18} \mathrm{O}$ and of $-1.00 \%$ o for $240 \quad \delta^{13} \mathrm{C}$ was applied to the isotope results from Uvigerina mediterranea to account for the 241 relatively constant offset (i.e. vital and habitat preferences) which is generally recorded 242 between both taxa (e.g. Schmiedl et al., 2004; Fontanier et al., 2006). 


\section{Results}

\subsection{Chronostratigraphy}

The12 uppermost metres of core MD01-2472 covers an interval of ca 56,000 y BP, i.e. MIS 3, MIS 2 and MIS 1, and includes the last glacial period and the HS (MIS 3 and 2), the glacial-interglacial transition (Termination I) and the present-day interglacial period (MIS 1, Holocene) (Toucanne et al., 2012) as shown in Table 2. Sedimentation rates of the uppermost $12 \mathrm{~m}$ range between 17 and $32 \mathrm{~cm} \mathrm{kyr}^{-1}$, with an average value of ca $22 \mathrm{~cm} \mathrm{kyr}^{-1}$.

\subsection{Sedimentological features}

Sedimentological analyses of core MD01-2472 reveals coarse-grained units, which are associated with a distinct change in the nature and distribution of sediments and sedimentary structures. These coarse-grained units are more pronounced during H2 and YD intervals (Figs. 2 and 3). The typical vertical succession includes (1) irregular negative grading, then positive grading in the sortable silt curve with a sandy silt bed at maximum grain size, (2) several sharp, gradational bioturbated sedimentary contacts, and (3) changes in bioturbation types (pyritized filaments in 'normal beds' and Planolites, Zoophycos and Thalassinoides in coarser-graded units, named 'mottled' units). The succession of grain-size modal curves shows poor to moderate sorting with a low negative skew (i.e. both coarse and fine tails; $c f$. Rivière, 1977). This relatively large fine tail is found even in the middle of the thicker units, which suggests that it is not only due to bioturbation but has a dynamic origin. The series of negative and positive grading is also evident on the modal curves. Alternations of moderately good and poor sorting are typically related to bioturbation and burrowing. Bioturbated facies are visible in X-ray images and thin sections, and appear as irregularly mottled silt, sand and mud (lithologies arranged in pockets, lenses and streaks, Fig. 3). All these features typify finegrained contourites as defined by Gonthier et al. (1984) and Stow et al. (1996). Coarseningupward profiles are characteristic of gradually increasing bottom current speed (along-slope transfer). Such fluctuations are progressive (due to long-term variations in currents) but may have occasionally been sudden as shown by sharp contacts, related to current instability and velocity pulsation (McCave and Hall, 2006). This sequence coincides with the gradual increase and gradual decrease of reworked microfossils found in the studied core section (plots in Figs. 2 and 3). 


\subsection{Microfaunal assemblages evolution since 56,000 years BP}

Cluster analyses of the microfossil assemblages reveals three benthic foraminiferal and two ostracod clusters. These clusters can be subdivided into subclusters (Figs. 4 and 5). The cumulative plots of each sub-cluster are shown in Figs. 6 and 7. We describe these subclusters as well as planktonic foraminifera distributions (Fig. 8) in stratigraphic order from MIS3 to MIS1.

The MIS 3 and MIS 2 (between $12 \mathrm{~m}$ and $3.2 \mathrm{~m}$ in core MD01-2472) are characterized by rapid alternation in relative abundances of all clusters (benthic foraminifera and ostracods). In these two intervals, the most common benthic foraminifera are species belong to clusters 3a (Hyalinea balthica and Bolivina spathulata), 3b (Bulimina marginata, Bolivina costata and G. altiformis) and 3c (C. wuellerstorfi, C. carinata, T. angulosa, Cibicidoides pachyderma, Hoeglundina elegans, and Quinqueloculina sp.) (Fig. 6). Ostracod assemblages equally allowed a good characterization of periods associated to MIS 3-MIS 2 and MIS 1. Elements belonging to clusters A2 (Bathycythere vanstraateni, Macrocypris sp.), A3 (Aurila sp., Callistocythere sp., and Hemicytherura videns), B3 (Semicytherura sp., Xestoleberis sp, Paradoxostoma sp. and Loxoconcha levis) and B4 (Echinocythereis echinata and Krithe spp.) are abundant (up to 13, 25, 50 and 60\%, respectively) during MIS 2 and MIS 3 whereas Polycope sp. is rare $(<5 \%)$ and inversely.

MIS 3 and MIS 2 are punctuated by H1-H5 events and short stadials and interstadials (Is in the figures). This climatic pattern is reflected in the highly variable abundances of all foraminifera and ostracods groups. Highest abundance of the polar species $N$. pachyderma $\mathrm{S}$ (Fig. 8) is observed in the HS. Allochthonous species (ostracods and benthic foraminifera) and ostracod species of clusters A3, B3 and B4 show maxima corresponding to HS and stadials. Peaks of ostracod species belonging to clusters B2, B1 and benthic foraminifera of cluster $3 \mathrm{~b}$ correspond to the Is, as calibrated by the ${ }^{14} \mathrm{C}$ dates. Warm water planktonic taxa do not exhibit consistent maxima during DO interstadials and T. quinqueloba species decrease in abundance in each Is phases. $\delta^{18} \mathrm{O}_{G}$. bulloides values are $>3 \%$ all along the MIS 3-MIS 2 interval.

The MIS 2 interval includes Last Glacial Maximum (LGM) period when $C$. wuellerstorfi gradually decreases in abundance associated with and an increase of species belonging to cluster 3a and cluster 3b, (Figs. 6 and 9). Among the ostracods, species of cluster A2 and B4 are typically abundant during this period of LGM, between 23,000 and 18,000 y BP. (Fig. 7). The planktonic foraminifera T. quinqueloba is at its maximum abundance peaks (up to $60 \%$ ), during the LGM period. 
Termination I (between $3.2 \mathrm{~m}$ and $2 \mathrm{~m}$ in core MD01-2472) is marked by high assemblage variability. Marked increases in the ostracod of Polycope sp. (38\%) and warm planktonic foraminifera occur during the B-A, whereas they markedly decrease in abundance

314 during the YD (Figs. 7 and 8). The B-A interval is typified by ostracods of Cluster A1 and of cluster B2 (Henryhowella sp., Pseudocythere caudata and Paracypris sp.), representing a marked increase in abundance (12\% and 50\%, respectively) during this period (Fig. 7). Allochthonous ostracods and Elphidium-Ammonia, magnetic susceptibility and sortable silt maximum values show maxima during the YD (Fig. 10). Krithe spp. and C. wuellerstorfi abundance also decreases in B-A event and increases during YD (Fig. 9).

MIS 1 (between $2 \mathrm{~m}$ and $0 \mathrm{~m}$ in core MD01-2472) corresponds to $\delta^{18} \mathrm{O}$ values of 1 $2 \% \delta^{18} \mathrm{O}_{G}$. bulloides. In this interval, the well-represented species are benthic foraminifera belonging to cluster 1 (Uvigerina mediterranea and Melonis barleeanus, ca 50\%), ostracod species part of cluster A1 (Monoceratina mediterranea, Bythocypris sp., up to 12\%) and benthic foraminifera of cluster 2 (Pseudoclavulina crustata, Chilostomella sp., B. nodosaria; ranging from 5 to 15\%) (Figs. 6 and 7). During MIS 1, planktonic foraminiferas $T$. quinqueloba and N. pachyderma are rare (Fig. 8), allochthonous elements (ostracods and foraminifera, Fig. 10) and ostracods of cluster B4, decrease markedly in abundance. Warm water planktonic foraminifera and Polycope sp. increase to 60 and $70 \%$ respectively in this interval (Figs. 7 and 8).

On Shannon index $(\mathrm{H})$ plots (ostracods and benthic foraminifera) the boundary between MIS 2 and MIS 1 is marked by a decrease in the microfaunal diversity (in benthic foraminifera and ostracod assemblages; Fig. 9).

The ecological significance of planktonic-benthic foraminifera and ostracods is listed 334 in appendix C.

\section{Discussion: Hydrodynamic conditions and water mass ventilation over the last 56,000 years}

\subsection{Greenland stadials/interstadials and LGM during MIS 3 and MIS 2}

The climate in the Western Mediterranean during stadials and HS, was characterized by relatively arid conditions as suggested by pollen reconstructions from marine and continental cores (Nebout et al., 2002; Sánchez Goñi et al., 2002, 2008). High aridity was mainly linked to the vigorous north-westerly winds that formed over the north-western 
346 Mediterranean due to a strong atmospheric pressure gradient in the North Atlantic 347 (Ganopolski and Rahmstorf, 2001). Previous studies (Moreno et al., 2005; Sierro et al., 2005; 348 Cacho et al., 2006; Frigola et al., 2008) have proposed a model of millennial scale variability for WMDW formation in the westernmost Mediterranean area (i.e. Alboran Sea) consisting in a stadial stimulation of deep ventilation produced by the reinforcement of north-westerly winds. Cold surface temperature and high salinities are thought to have affected intermediate and deep ocean convection by accelerating the vertical mixing that resulted in the intensification of bottom currents and weak water mass stratification (Rohling et al., 1998).

In the studied core, HS can readily be identified by maxima of polar planktonic foraminifera $N$. pachyderma $\mathrm{S}$ (except H3, Fig. 8). There is a good correlation between the $C$. wuellerstorfi, Krithe spp. abundance (two benthic species indicator of oxygenationed conditions; see appendix C) and the $\mathrm{O}_{2}$ index occurs during stadial intervals and HS (Fig. 9) suggesting enhanced bottom water oxygenation in the Corsica Trough during this time. Krithe spp. are more abundant during cold periods in the Atlantic Ocean (Cronin et al., 1996) and in the Mediterranean Sea (Bassetti et al., 2010). The genus Krithe is a common component of global deep-sea ostracod assemblages (Dingle and Lord, 1990). We suggest that increases in Krithe spp. abundance in core MD01-2472 during stadials and HS reflects enhanced bottom oxygenation, associated with a lowering of bottom water temperature, also suggested by benthic oxygen isotope ratios (Toucanne et al., 2012).

The results from grain-size analyses in this work have greatly increased the resolution of the data obtained by Toucanne et al. (2012). The sortable silt record of core MD01-2472 reveals 2-4 $\mu \mathrm{m}$ positive shifts during stadials and HS (Fig. 10). In detail, in terms of lithofacies, the sedimentary sequences during H2 (Fig. 2), are composed of muddy and silty mottled facies forming coarsening-up and fining-up units, interpreted to be contourite deposits (Gonthier et al., 1984; Stow et al., 1986). Increases in bottom current intensity in the Corsica Trough during cold intervals (Toucanne et al., 2012) caused increased oxygenation. Enhanced bottom ventilation is corroborated by the increase of benthic $\delta^{13} \mathrm{C}$ observed in the studied core (Fig. 9). Bioturbation by Planolites and Thalassinoides typically occurred during the cold phases (Fig. 2) associated with coarse sediment with low total organic carbon (TOC) and high energy hydrodynamic conditions (Löwemark et al., 2004). These intervals contain Trifarina angulosa, a taxon that may be a good indicator of strong bottom current (Mackensen et al., 1993; Harloff and Mackensen, 1997) and common reworked shallow water benthic foraminifera. Allochthonous ostracods (species of cluster A3 and of clusters B3, Fig. 7) from the continental shelf and the upper slope are also present associated with evidence for 
winnowing of fine particles and contourite deposition in the studied area (Toucanne et al., 2012) suggesting transport by vigorous LIW at site MD01-2472 during stadials and HS.

In contrast, allochthonous specimens at site MD01-2472 during Is is relatively rare $(<1 \%$ for Elphidium/Ammonia group, $<20 \%$ for allochthonous ostracods, Fig. 10) suggesting minor sediment transfer from the shelf and along the slope at this time. The benthic $\delta^{13} \mathrm{C}_{U}$. peregrina records show the lowest values during Is (Fig. 9), which may be linked to higher bottom-water residence times associated with decreased LIW ventilation. Moreover, $T$. quinqueloba is relatively rare during Is suggesting a weak surface productivity (Parker, 1971; Hemleben et al., 1989; Kroon, 1991; Johannessen et al., 1994; Rasmussen et al., 2003).

The highly variable benthic $\delta^{13} \mathrm{C}$ values during warm phases of the last glacial period are difficult to interpret. The values may be related to longer bottom-water residence times in the Corsica Trough during interstadials (i.e. high $\delta^{13} \mathrm{C}$ values, $>0.5 \%$ ) since they correlate to intervals with low $\mathrm{O}_{2}$ indices ( $<0.8$, Fig. 9) and weak surface productivity (Fig. 8). In addition, this hypothesis is supported by maxima of ostracod clusters B1 and B2 (Fig. 7), including Paracypris sp. and. Argilloecia acuminata, species adapted to poorly oxygenated environments (Cronin, 1983; Andreu, 1992; Alvarez Zarikian et al., 2009). Benthic foraminifera of cluster $3 \mathrm{~b}$ (B. marginata, B. costata and G. altiformis) also increase in abundance during Is (Fig. 6) suggesting reduced oxygenation. Pyritized filaments are the most common bioturbation types in fine grained sediment during interstadials (Fig. 2), associated with high TOC (Löwemark et al., 2004) suggesting a slight decrease in LIW ventilation and lower bottom water oxygenation in the Corsica Trough during Is.

The highest abundance of $T$. quinqueloba, a taxon related to high surface primary productivity and cold sea surface temperatures, is observed in the LGM associated with an increase of benthic species of clusters 3a-3b (benthic foraminifera, Fig. 6) and clusters A2-B4 (ostracods, Fig. 7). This indicates a rapid response of benthic fauna to nutrient enhancement linked to the surface productivity. It may also explain the reduction in $\mathrm{O}_{2}$ index values, due to organic matter degradation. However, Schmiedl et al. (2003) interpret $\mathrm{O}_{2}$ index values between 0.9 and 0.7 to indicate well-oxygenated waters. Thus, the sea floor was well ventilated during the LGM period in Corsica Trough. Similarly, Abu-Zied et al. (2008) used on benthic foraminifera in the Eastern Mediterranean to interpret well ventilated bottom waters during LGM times, Di Donato et al. (2009) also interpret oxic sea floor conditions in the Gulf of Salerno (southern Tyrrhenian Sea). 
Allochtonous species (foraminifera and ostracods) were rare during the LGM period and any evident grain-size increase is observed in the sediment interval corresponding to the 416 LGM (Fig. 10). It is possible that bottom flow intensity may not have been strong enough to carry heavier sediment particles in suspension or that the LIW axis was deeper, thus controlling sediment transport mainly in the deep Golo Basin, as shown by Toucanne et al. (2012) in core MD01-2434. Moreover, the LGM period is marked by sea level drop (-120/$130 \mathrm{~m}$ under the actual level in Tyrrhenian Sea, Lambeck et al., 2011). The Mediterranean ocean climate modeling made by Mikolajewicz (2011) during this period, shows a strongest cooling in summer in the northwestern Mediterranean and weak cooling in the Levantine basin with a weak LIW formation. Thus, this decrease of LIW formation associated to the sea level fall could have conduct to the diminution of LIW velocity and can explain the absence of allochtonous species and negligible grain-size increase in Golo Basin during this period.

\section{2. Termination I}

Termination I includes the B-A and the YD events. Similar to other paleoclimatic studies in the Tyrrhenian Sea (e.g. Paterne et al., 1999 among others), a marked increase of warm water planktonic assemblages at the end of the last glacial period coincides with the BA period (Fig. 8), while cold water planktonic assemblages characterise the YD period. Peaks in abundance of Paracypris sp. and Polycope sp. (Fig. 7) suggest reduced dissolved oxygen during the B-A at the water-sediment interface, coinciding with reduced of Krithe spp. and $C$. wuellerstorfi abundance (Fig. 9) in the B-A, and a lower $\mathrm{O}_{2}$ index (Fig. 9) that suggests slightly under-oxygenated conditions. In contrast Krithe spp. and C. wuellerstorfi become common during the YD interval, associated abundant allochthonous ostracods (Fig. 10) and reworked benthic foraminifera (Elphidium/Ammonia group, Fig. 10).

Marked changes in facies occurred during the YD period, with the deposition of a 0.75-metre-thick silty unit at site MD01-2472 (Fig. 3). The sediment facies characterized by a coarseaning followed by fining upward with no evidence of basal erosion (Fig. 3) suggest that these features are not turbidites. These sediments are interpreted as contourites and related to episodes of bottom current reinforcement. We suggest enhanced LIW ventilation during the

443 YD event was forced by rapid climatic changes in the Mediterranean, during cold and dry conditions (Kotthoff et al., 2008; Combourieu-Nebout et al., 2009).

Any significant sea-level fall has been described for the YD along the Italian coast

446 (Lambeck et al., 2011), but evidence of a global sea-level rise deceleration has been observed 447 before the Holocene (Bard et al, 2010). On the other hand and at the local scale, Caruso et al. 
(2011) present evidence of a possible sea-level variation in the northern part of the Sicilian coast between 12 and $14 \mathrm{ka}$ that culminates during the YD. The latter hypothesis must be verified and supported by regional evidence, but either a relative sea-level fall of small amplitude or a deceleration of the sea level rise, together with a significant reinforcement of the LIW velocity could have played a major role in the reworking of benthic species from the inner shelf and contribute in the formation of the YD contourite in the East Corsica continental slope.

\section{3. Holocene (MIS 1)}

The relationship between Holocene climate variability in the Western Mediterranean and Atlantic climate is not well established, since marine sediment records with high sedimentation rates are rare (Rohling and Gieskes, 1989; Rohling and De Rijk, 1999; Rohling et al., 2002; Mayewski et al., 2004; Combourieu-Nebout et al., 2013; Magny et al., 2013; Sadori et al., 2013; Sicre et al., 2013). Recent works analyses of deep-water contourite drifts in the western Mediterranean (Frigola et al., 2007; Melki et al., 2009) highlight the effects of

463 Holocene climate variability on Mediterranean thermohaline circulation. In particular, geochemical and sedimentological proxies suggest global deep-water circulation slowed during the early Holocene $(11,700 \mathrm{y}-10,500 \mathrm{y} \mathrm{BP})$ due to the combined effect of rising sealevel and relatively humid climate conditions on land (Peyron et al., 2012). Between 10,500 y and 7,000 y BP the deep-water circulation strengthened until the end of the rapid sea-level rise, followed by a gradual weakening of circulation (to modern times) related to the stability of atmospheric conditions (Frigola et al., 2007).

In core MD01-2472, we do not have sufficient resolution to identify rapid climatic events. Nevertheless, we focus on the long-term patterns can be interpreted from the microfauna assemblages. The high abundance of warm water planktonic species in the Holocene interval (up to $60 \%$, Fig. 8) is related to the increase of atmospheric and sea surface temperature during the last interglacial onset as shown by the planktonic $\delta^{18} \mathrm{O}$ values in the Corsica Trough. Polycope ostracod species reach a maximum abundance during the Holocene (varying from 20 to $70 \%$, Fig. 7) suggesting low current velocities and lower bottom water oxygenation (Cronin et al., 1995). The decrease of allochthonous species (ostracods of cluster A3, benthic foraminifera of clusters 3c) and low SS and magnetic susceptibility (Fig. 10) may be due to a reduction in bedload transport in low-energy bottom water conditions. Krithe spp. are rare in this interval, suggesting either a lowering in dissolved oxygen content or a decrease 
period (Fig. 8) weak surface primary productivity (Rasmussen et al., 2003) and the increase of

$483 U$. mediterranea and M. barleeanus (Cluster 1, 50\%, Fig. 6) indicates overall bottom oligo484 mesotrophic sea floor conditions (Fontanier et al., 2003).

485

486

487

488

489

490

491

492

493

494

495

496

497

498

499

500

501

502

503

504

505

506

507

508

509

510

511

512

513

514

515

\section{Conclusions}

We have used microfossils in a deep sea core (MD01-2472) to reconstruct a 56,000 year record of bottom water trophic variability and LIW circulation change in the Corsica Trough, northwestern Tyrrhenian Sea. Analyses of planktonic and benthic foraminiferal and as well as ostracods assemblages reveal strong bottom water environmental variability over the last 56,000 years. Intervals with Krithe spp. (ostracod), C. wuellerstorfi (benthic foraminifera) indicate bottom water oxygenation during stadials (MIS 3 and MIS 2), whereas interstadials are typified by A. acuminata and Paracypris sp (ostracods) indicating poorly oxygenated environments. The LGM is dominated by $T$. quinqueloba that suggesting high surface primary productivity associated with the establishment of meso-eutrophic bottom conditions. During the Holocene, microfaunal assemblages indicate oligo-mesotrophic bottom conditions and low-energy bottom conditions. Considering the present-day hydrological structure in the Corsica Trough, our data reveal that intensified LIW inflow and ventilation during the last glacial interval (particularly during by Greenland stadials) followed by weaker LIW ventilation during the Holocene.

\section{Acknowledgments}

We would like to thank M. Lahmi and N. Touyet for sampling, sieving and measuring grain-sizes on MD01-2472 samples; K. Charlier for isotopic analyses; and the crew and scientific teams of the R/V Marion Dufresne II (MD124-Geosciences 2 cruises) for the recovery of the piston cores.

We thank the ARTEMIS Mass Spectrometer Accelerator Laboratory (Saclay, Gif-surYvette) for providing ${ }^{14} \mathrm{C}$ dates, and the European Science Foundation and IODP France for funding the participation of C.M. Angue Minto'o at the $9^{\text {th }}$ Urbino Summer School in Paleoclimatology (2012), which provided better knowledge of the paleocenographic tools used in this paper.

G. Schmiedl is gratefully aknowledged for comments and discussion on the calculation of the $\mathrm{O}_{2}$ index. 
517 manuscript, and providing useful suggestions. We are grateful to the anonymous reviewer and 518 the Chief Editor N. Catto for constructive comments.

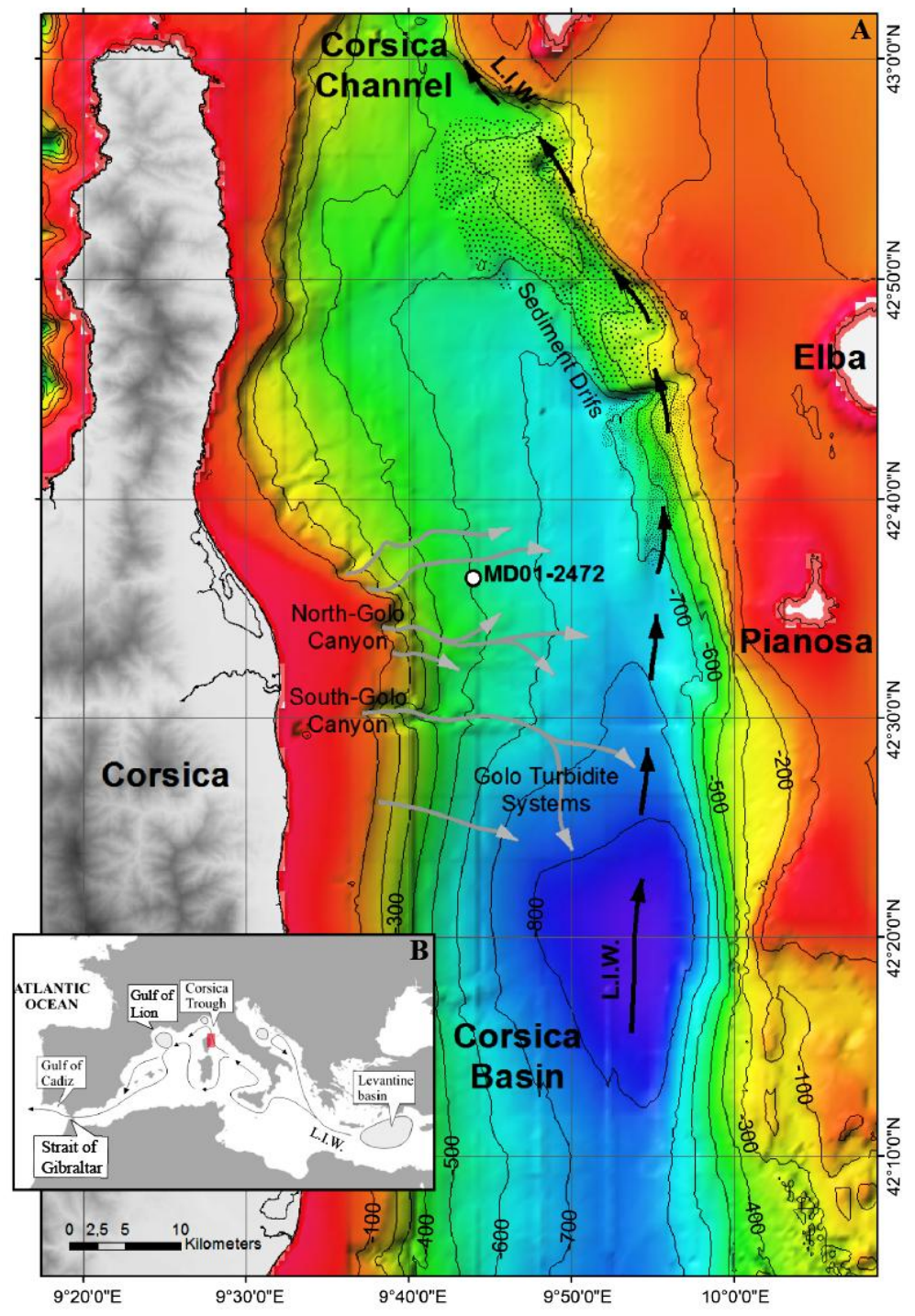

Fig. 1 - Angue Minto'o et al.

\section{Figure 1:}

522 A. Bathymetry of the Golo margin and location of core MD01-2472. Black arrows indicate

523 the main path of the LIW (Levantine Intermediate Water) in East Corsica basin. The grey

524 arrows show the general distribution of sedimentary supplies in the basin. B. General 525 circulation of the LIW in Mediterranean Sea from Levantine basin to Strait of Gibraltar. 


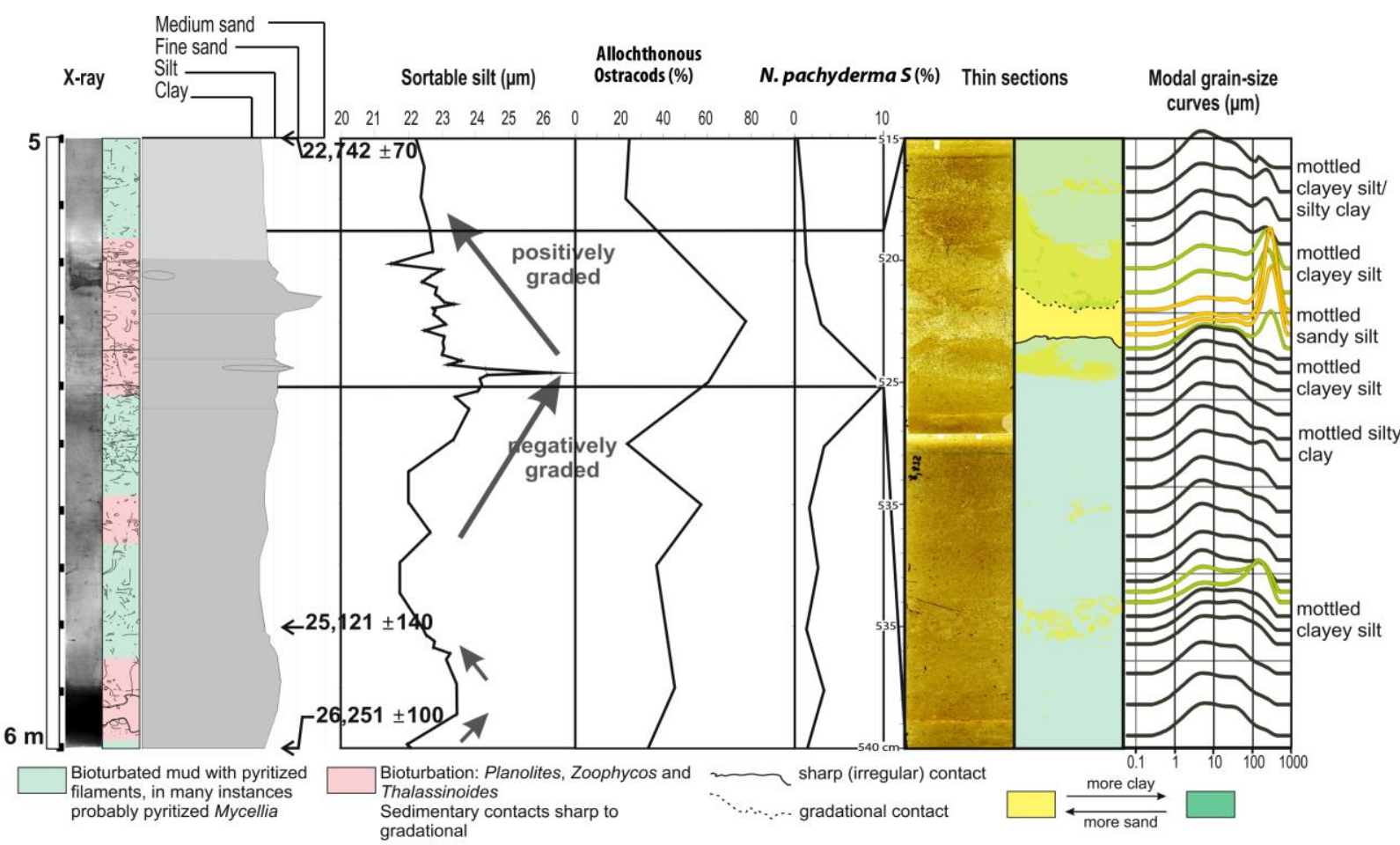

Fig. 2 - Angue Minto'o et al.

\section{Figure 2:}

529 Detail of sedimentary sequence corresponding to the H2. From left to right: X-ray image,

530 interpretative drawing with bioturbation and sedimentary contacts, lithological log with D50

531 as indicated grain size, radiocarbon dates (y cal. BP) indicated with black arrows, sortable silt,

532 allochthonous ostracod species and Neogloboquadrina pachyderma S percentage curves,

533 indurated thin sections between 515 and $540 \mathrm{~cm}$ with its interpretative drawing and grain-size

534 histograms related to thin sections. 


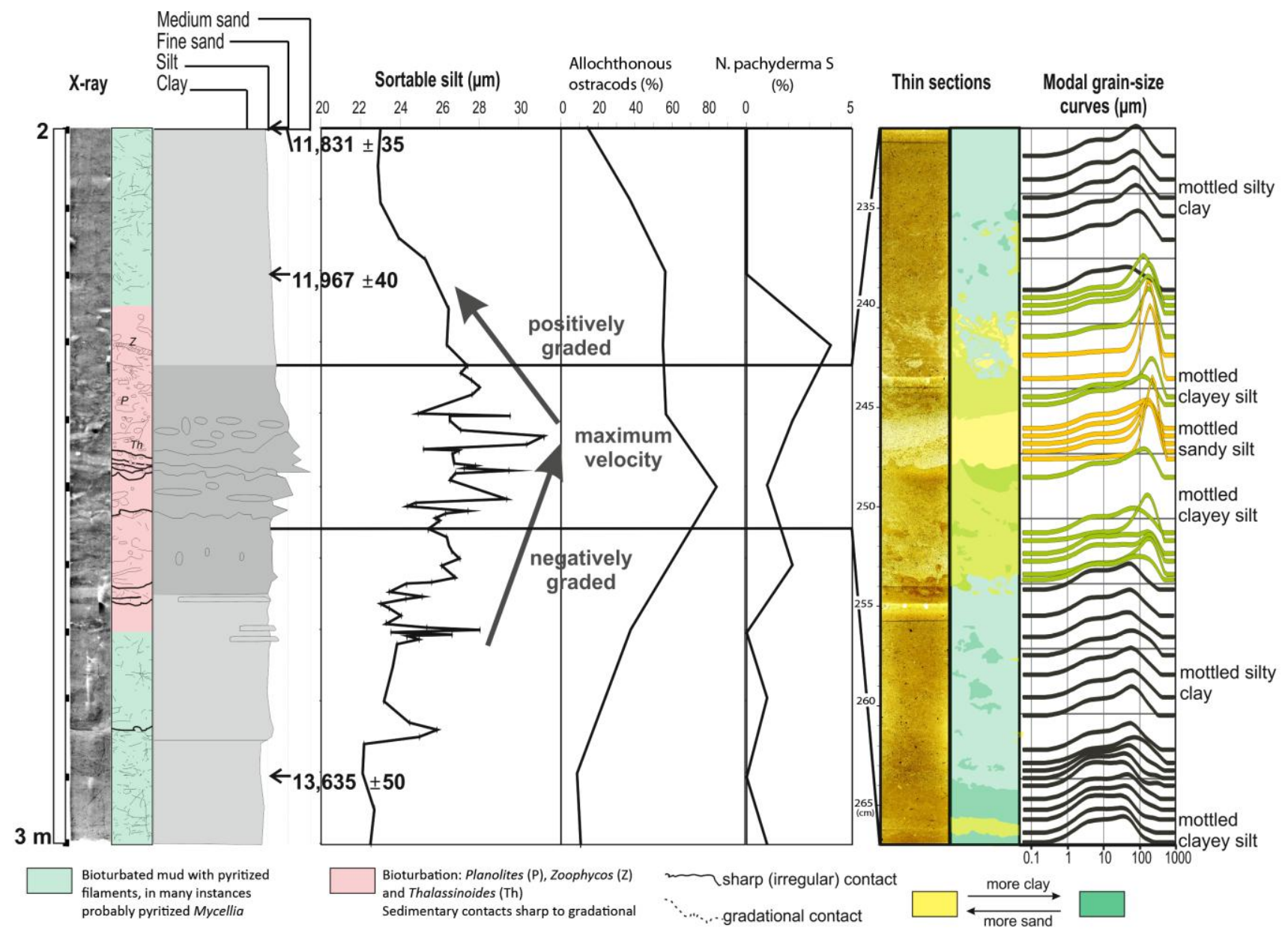

Fig. 3 - Angue Minto'o et al.

537 Figure 3: Detail of the YD sequence. From left to right : X-ray image, interpretative drawing

538 with bioturbation and sedimentary contacts, lithological log with D50 as indicated grain size,

539 radiocarbon dates (y cal. BP) indicated with black arrows, sortable silt, allochthonous

540 ostracod species and Neogloboquadrina pachyderma S percentage curves, indurated thin

541 sections between 231 and $267 \mathrm{~cm}$ with its interpretative drawing and grain-size histograms

542 related to thin sections. 


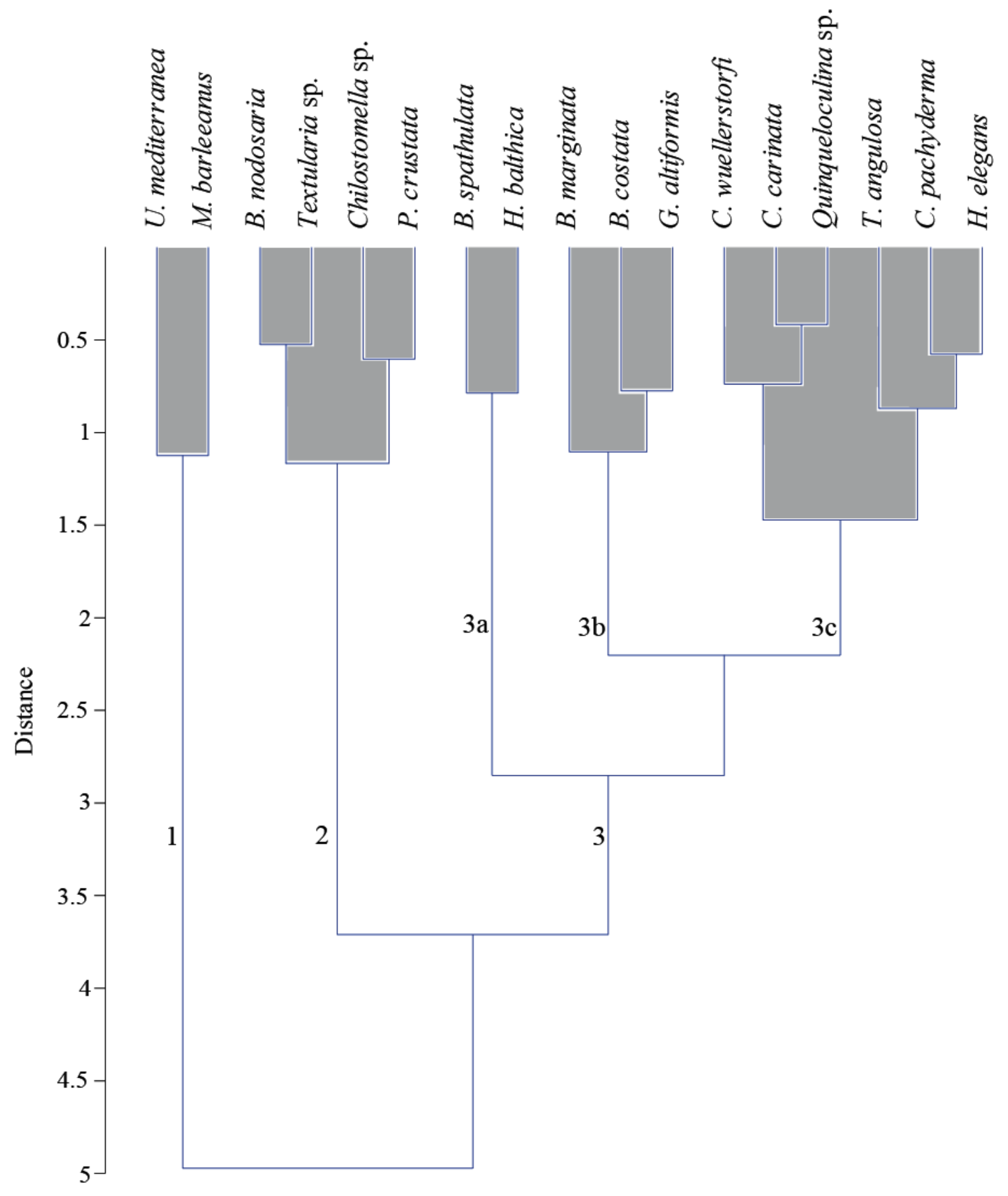

Fig. 4 - Angue Minto'o et al.

\section{Figure 4:}

546 Dendrogram of benthic foraminifera resulting from R-mode cluster analysis, using Ward's

547 distance. Three main clusters are recognized. Cluster 3 is subdivided into three sub-clusters 548 (3a, 3b and 3c). 

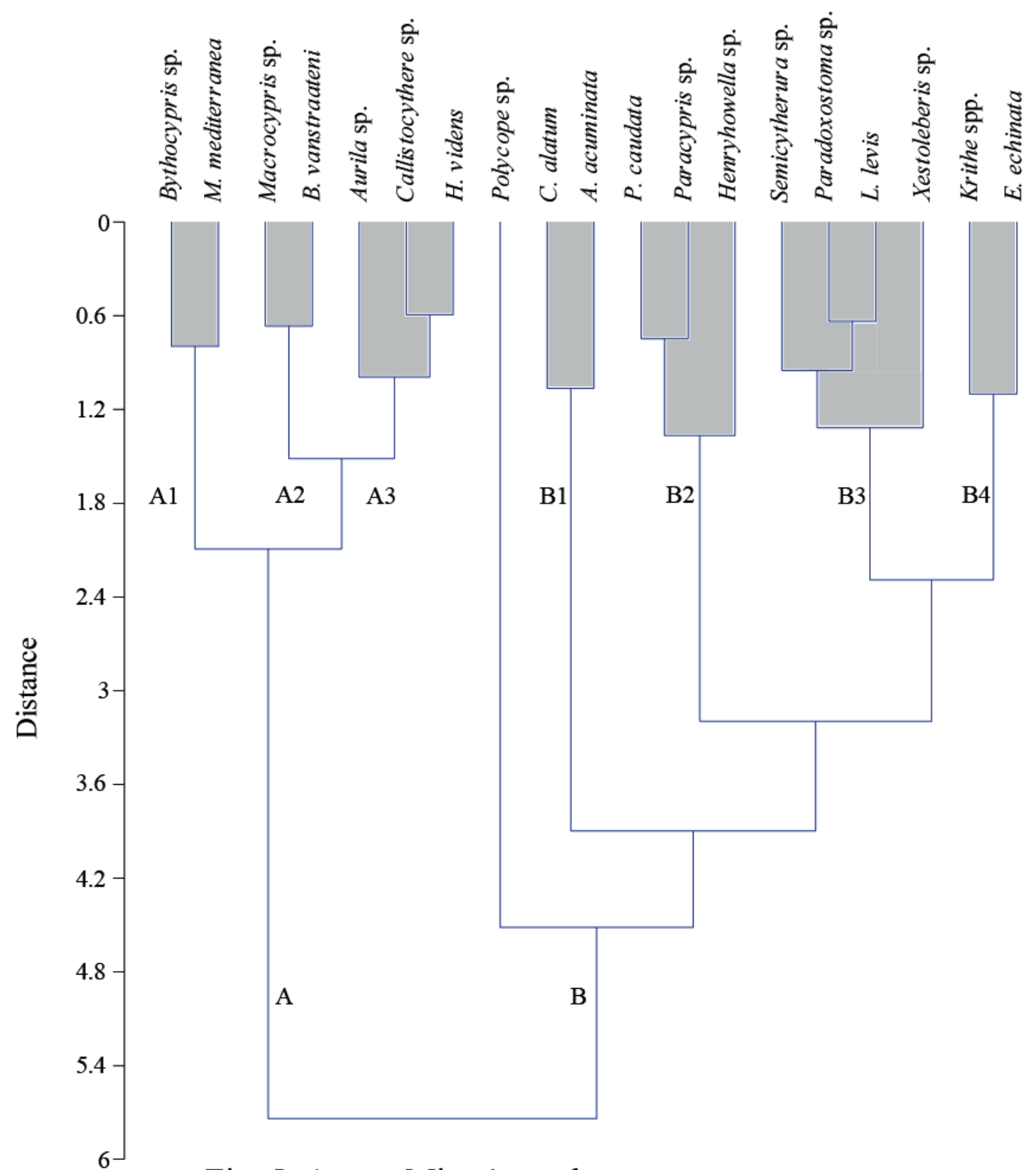

Fig. 5- Angue Minto'o et al.

\section{Figure 5:}

552 Dendrogram of ostracods resulting from R-mode cluster analysis, using Ward's distance. Two

553 main clusters are recognized and are subdivided into seven sub-clusters (A1, A2, A3, B1, B2,

554 B3 and B4). Polycope sp. shows very low correlation with all the other species and it cannot 555 be associated to any of clusters. 


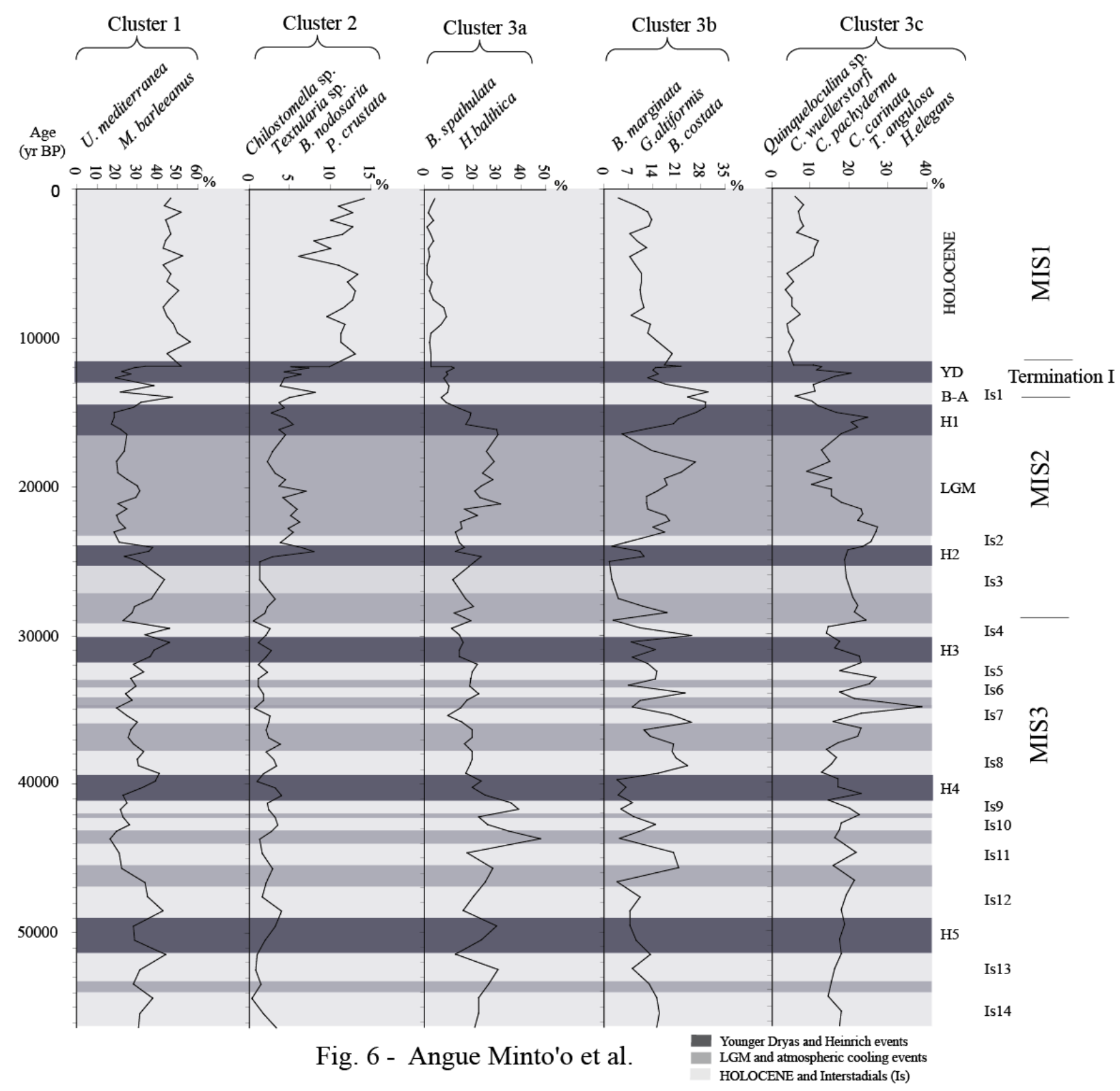

\section{Figure 6:}

559 The cumulative plots of benthic foraminifera from cluster analysis. Curves show microfauna 560 distribution along the core according to age. MIS 3 and MIS 2 periods are characterized by 561 benthic foraminifera of cluster 3a (Bolivina spathulata, Hyalinea balthica), 3b (Bulimina 562 marginata, Gyroidina altiformis and Bulimina costata) and 3c (Quinqueloculina sp., 563 Cibicidoides wuellerstorfi, Cibicidoides pachyderma, Cassidulina carinata, Trifarina 564 angulosa and Hoeglundina elegans). MIS 1 is characterized by Melonis barleeanus, 565 Uvigerina mediterranea (cluster 1) and Chilostomella sp., Textularia sp., Bigenerina 566 nodosaria, Pseudoclavulina crustata (cluster 2). 


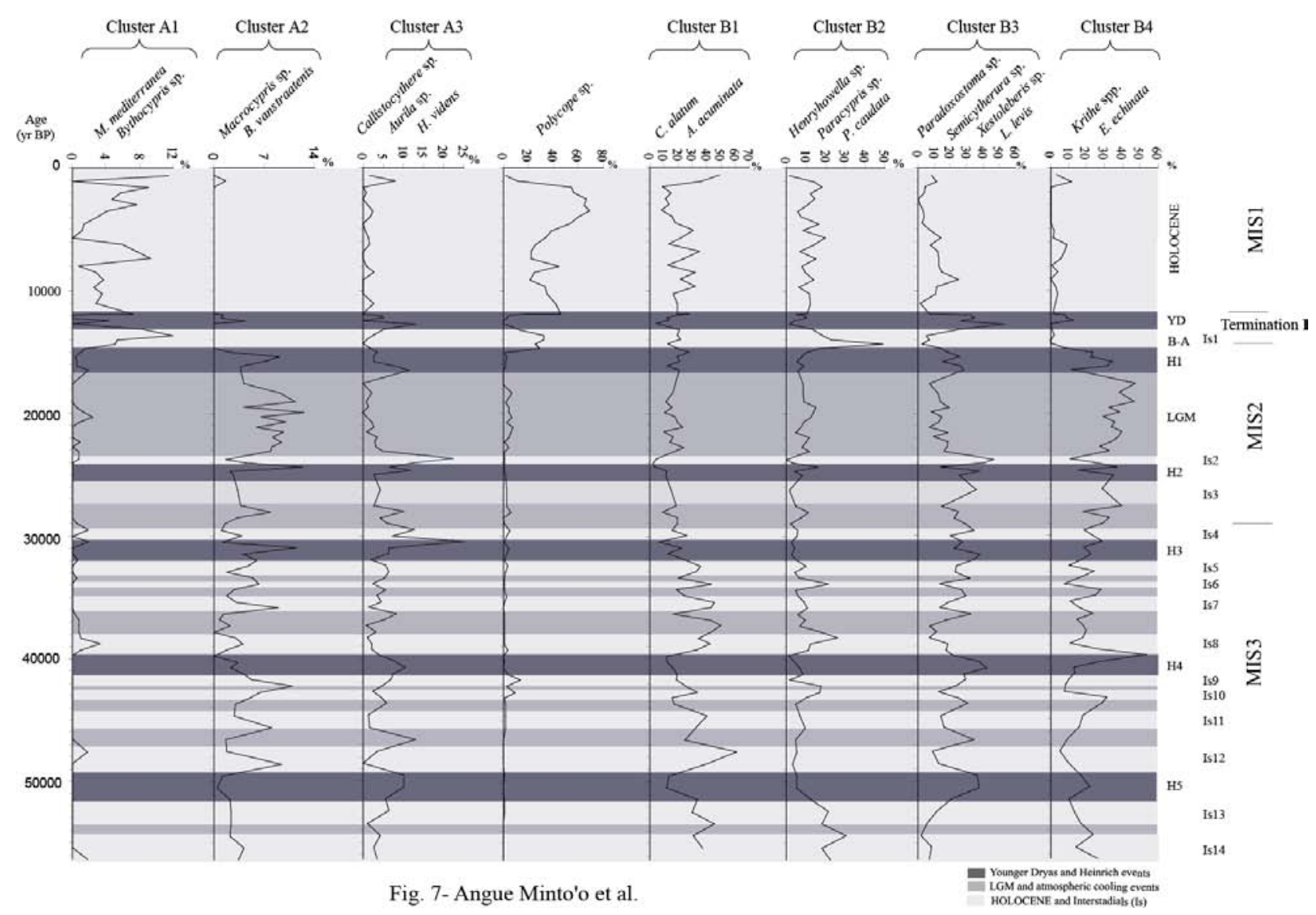

\section{Figure 7:}

570 The cumulative plots of ostracods from cluster analysis. Curves show microfauna distribution

571 along the core according to age. MIS 3 and MIS 2 periods are characterized by ostracods of 572 cluster A2 (Macrocypris sp., Bathycythere vanstraateni,), Cluster A3 (Callistocythere sp., 573 Aurila sp., Hemicytherura videns), cluster B3 (Paradoxostoma sp., Semicytherura sp. 574 Xestoleberis sp. and Loxoconcha levis) and cluster B4 (Krithe spp. and Echinocythereis 575 echinata). MIS 1 is characterised by species such as Monoceratina mediterranea, Bythocypris 576 sp. (Cluster A1) and by Polycope sp.. The B-A interval is well characterised by species of 577 cluster B2: Henryhowella sp., Paracypris sp., and Pseudocythere caudata. 


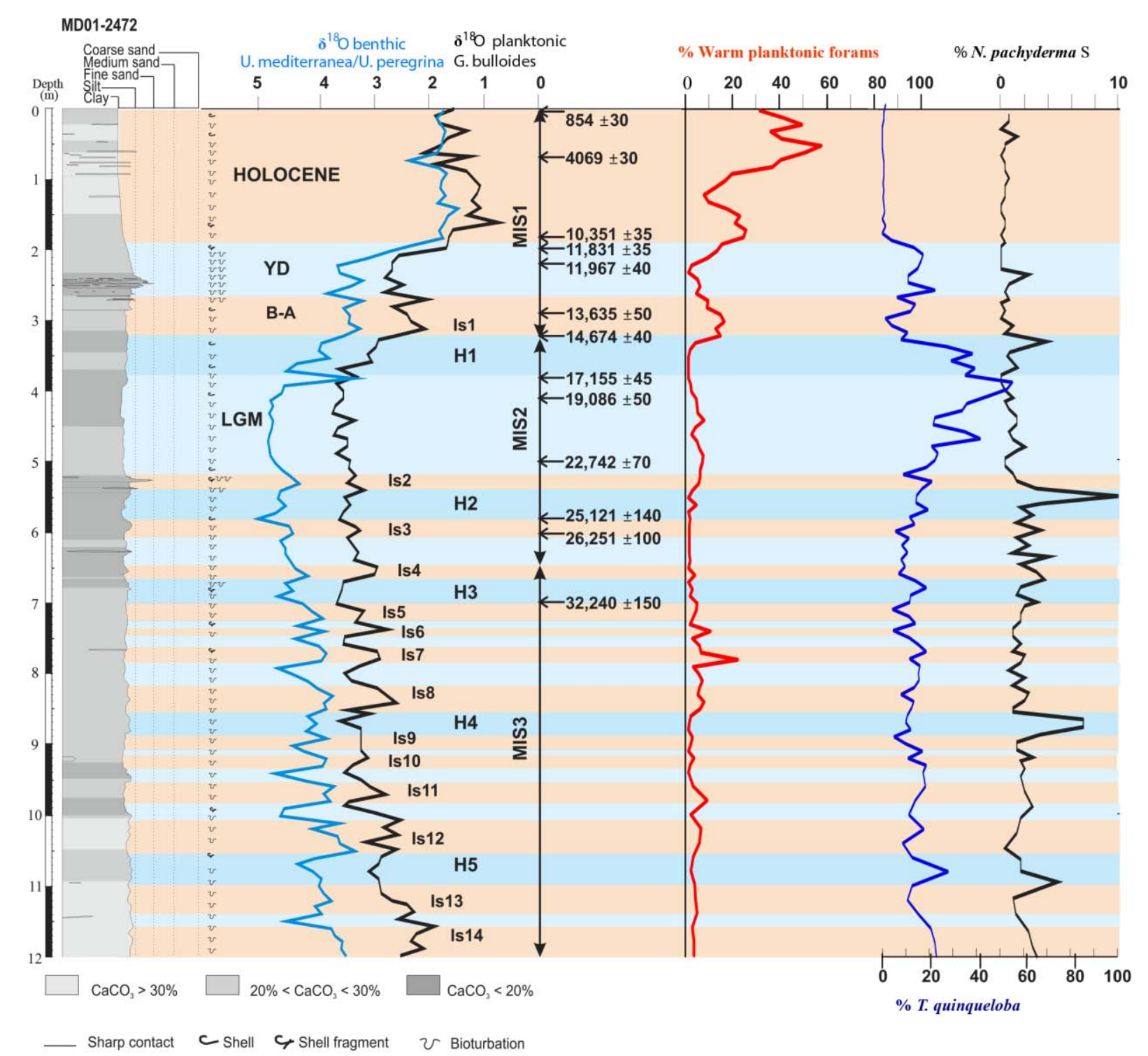

Fig. 8 - Angue Minto'o et al.

\section{Figure 8:}

581 Stratigraphy of core MD01-2472, from left to right: lithological log with D50 as indicated 582 grain size, benthic and planktonic $\delta^{18} \mathrm{O}$ curves, radiocarbon dates (yr cal. BP) indicated by 583 black arrows and distributions curves of warm planktonic foraminifera, Turborotalia 584 quinqueloba and Neogloboquadrina pachyderma S. Rapid climate oscillations identified in 585 core MD01-2472 are: YD (Younger Dryas), BA (Bolling-Allerød), H1 to H5 (Heinrich event 5861 to 5), Is (Greenland interstadial). 


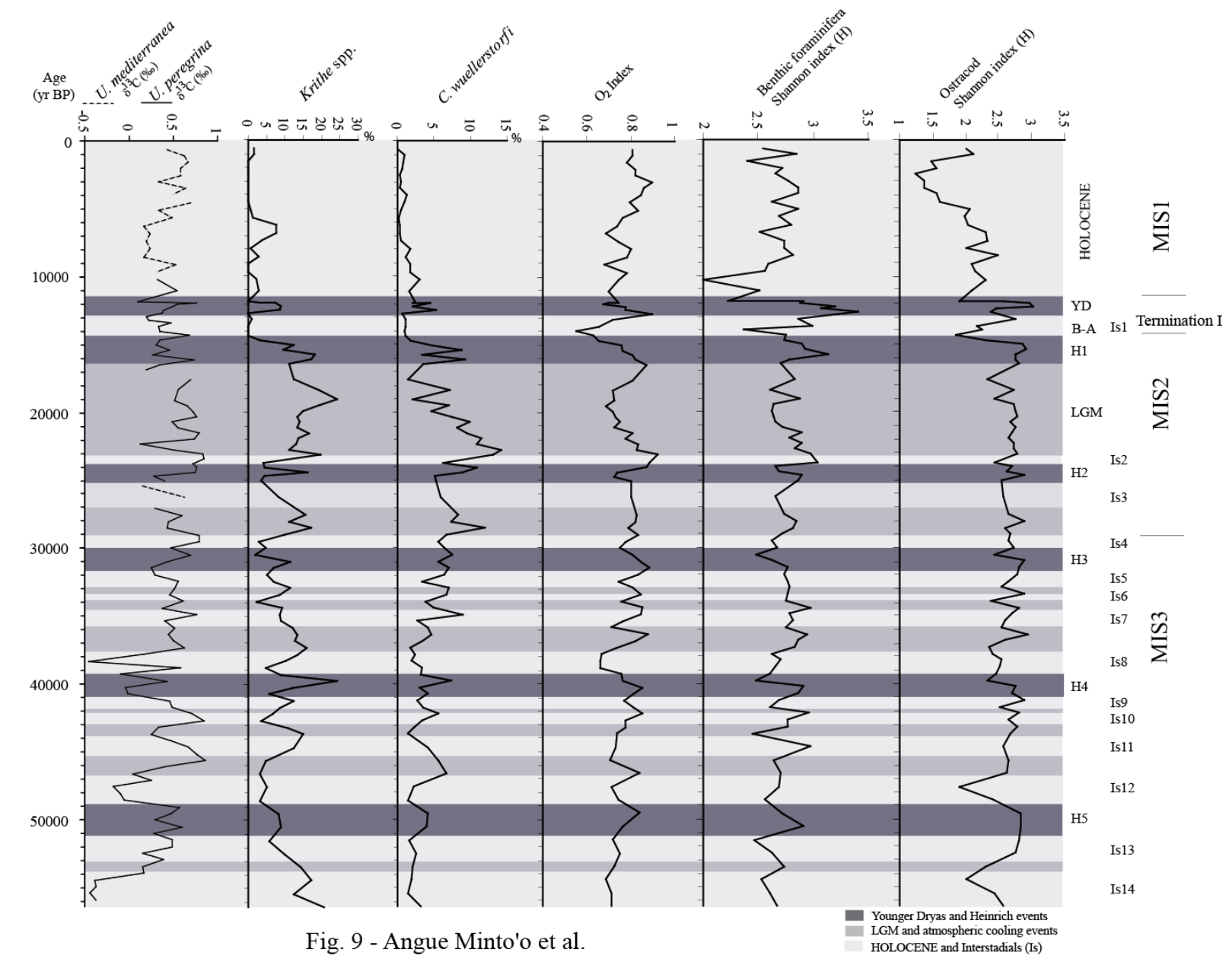

Fig. 9 - Angue Minto'o et al.

589 Figure 9:

590 Alongcore variation according to age of: $\delta^{13} \mathrm{C}$ ratios measured on benthic foraminifera $U$.

591 mediterranea and $U$. peregrina; Krithe spp. (ostracods) and C. wuellerstorfi (benthic 592 foraminifera) relative abundance; $\mathrm{O}_{2}$ index (calculated using the formula proposed by 593 Schmiedl et al., 2003); Shannon index (H) of benthic foraminifera and ostracods. 


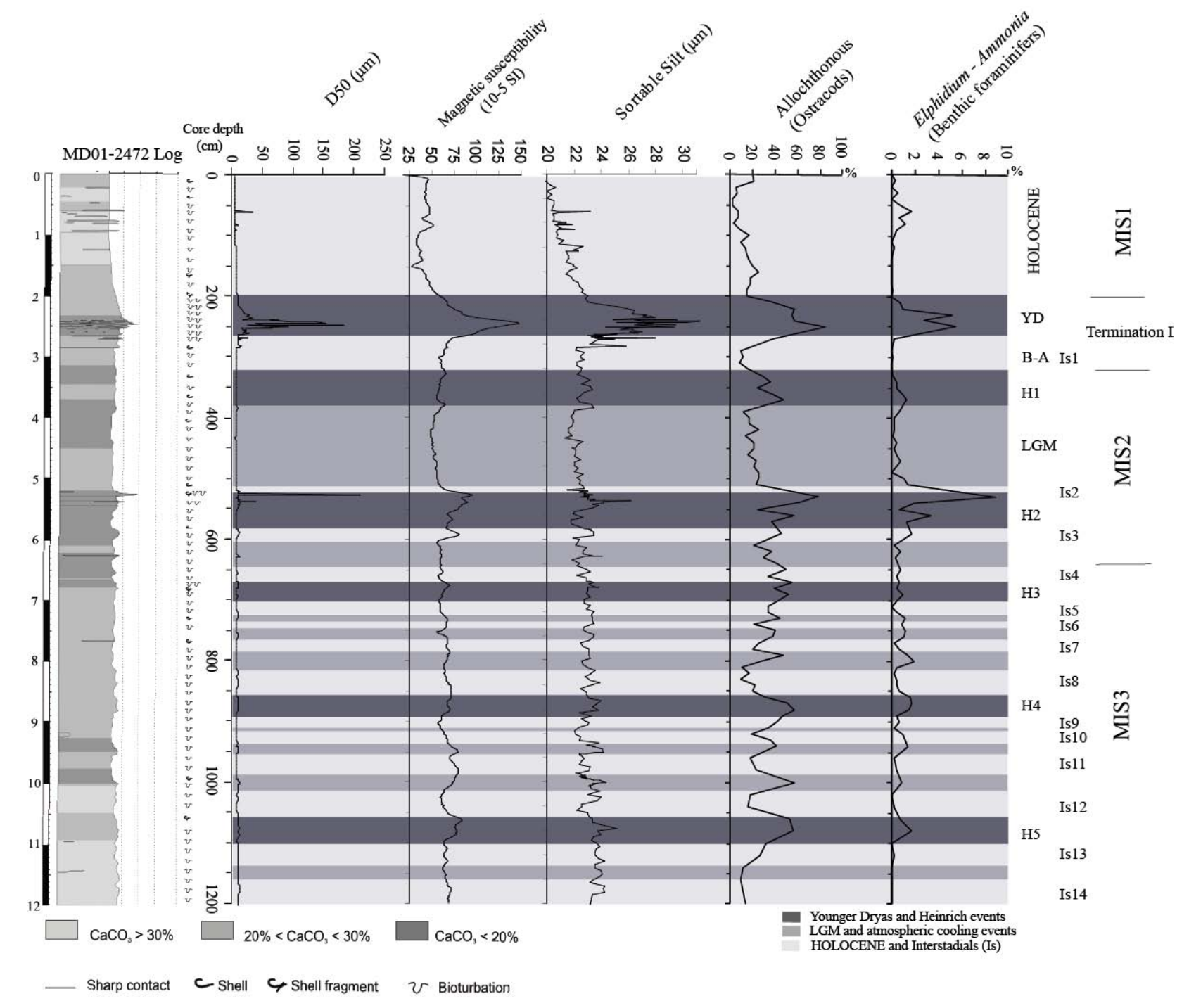

Fig. 10 - Angue Minto'o et al.

\section{Figure 10:}

597 D50, magnetic susceptibility and sortable silt (SS) values correlated with allochthonous 598 ostracods species (Pontocythere elongata, Heterocythereis albomaculata, Xestoleberis sp., 599 Paradoxostoma sp., Semicytherura sp., Loxoconcha levis, Carinocythereis sp., 600 Hemicytherura videns, Hiltermanicythere turbida, Pseudocytherura calcarata, Costa sp., 601 Aurila sp., Callistocythere sp.) and Elphidium/Ammonia spp. To be notice the good 602 correlation between the magnetic susceptibility, allochthonous ostracods and 603 Elphidium/Ammonia spp. (reworked foraminifera) curves. Abundance peaks of allochthonous ostracods and Elphidium/Ammonia spp. curve correspond to HS (cold phases). 


\begin{tabular}{|c|c|c|c|c|c|c|}
\hline $\begin{array}{l}\text { Depth } \\
(\mathrm{cm})\end{array}$ & Material & Lab code & $\begin{array}{l}\text { Corrected }{ }^{14} \mathrm{C} \\
\text { age (yr BP) }\end{array}$ & $\begin{array}{l}\text { Cal BP age } \\
\text { ranges }(2 \sigma)\end{array}$ & $\begin{array}{l}\text { Cal BP age } \\
\text { median } \\
\text { probability }\end{array}$ & Data origin \\
\hline 5 & bulk planktic & SacA19752 & $910 \pm 30$ & $760-916$ & 842 & Toucanne et al., 2012 \\
\hline 70 & bulk planktic & SacA19754 & $3645 \pm 30$ & $3,875-4,009$ & 3,960 & Toucanne et al., 2012 \\
\hline 180 & bulk planktic & SacA19756 & $9100 \pm 35$ & $10,196-10,298$ & 10,244 & Toucanne et al., 2012 \\
\hline 200 & bulk planktic & SacA19756 & $10170 \pm 35$ & $11,712-12,026$ & 11,875 & this study \\
\hline 220 & bulk planktic & SacA19757 & $10,240 \pm 40$ & $11,812-12,121$ & 11,990 & Toucanne et al., 2012 \\
\hline 290 & bulk planktic & SacA19753 & $11,790 \pm 50$ & $13,453-13,786$ & 13,641 & Toucanne et al., 2012 \\
\hline 320 & bulk planktic & SacA19753 & $12,510 \pm 40$ & $14,224-15,070$ & 14,684 & this study \\
\hline $380^{*}$ & bulk planktic & SacA19758 & $13,720 \pm 45^{*}$ & $16,692-17,018$ & $16,850^{*}$ & Toucanne et al., 2012 \\
\hline 410 & bulk planktic & SacA19753 & $15,870 \pm 50$ & $18,828-19,345$ & 19,091 & this study \\
\hline 500 & bulk planktic & SacA19753 & $19,090 \pm 70$ & $22,396-23,034$ & 22,751 & this study \\
\hline 580 & bulk planktic & SacA19755 & $21230 \pm 140$ & $24,962-25,867$ & 25,367 & Toucanne et al., 2012 \\
\hline 600 & bulk planktic & SacA19760 & $22380 \pm 100$ & $26,558-27,716$ & 27,063 & Toucanne et al., 2012 \\
\hline 700 & bulk planktic & SacA19753 & $27,860 \pm 150$ & $31,493-32,610$ & 31,948 & this study \\
\hline
\end{tabular}

610 Table 1:

611 Radiocarbon ages of core MD01-2472. The dates were corrected for a marine reservoir effect

612 of $400 \mathrm{y}$, except for the period 15,000-17,000 y BP (marked by an asterisk) to which a

613 correction of 800 y was applied (cf. Siani et al., 2001). Radiocarbon ages were calibrated to

614 calendar years using CALIB 6.0.1 and the IntCal09 calibration curve (Reimer et al., 2009).

615

\begin{tabular}{ccc}
\hline Depth(cm) & Events & Proxy \\
\hline $265-320$ & Is1 & ${ }^{14} \mathrm{C}$ \\
$320-375$ & $\mathrm{H} 1$ & $\delta^{18} \mathrm{O}^{*}$ \\
$520-540$ & Is2 & ${ }^{14} \mathrm{C}$ \\
$540-580$ & $\mathrm{H} 2$ & $\delta^{18} \mathrm{O}^{*}$ \\
$580-605$ & Is3 & ${ }^{14} \mathrm{C}$ \\
$645-665$ & Is4 & ${ }^{14} \mathrm{C}$ \\
$665-700$ & $\mathrm{H} 3$ & $\delta^{18} \mathrm{O}^{*}$ \\
$700-725$ & Is5 & ${ }^{14} \mathrm{C}$ \\
$735-745$ & Is6 & ${ }^{14} \mathrm{C}$ \\
$760-785$ & Is7 & ${ }^{14} \mathrm{C}$ \\
$820-855$ & Is8 & ${ }^{14} \mathrm{C}$ \\
$855-890$ & H4 & $\delta^{18} \mathrm{O}^{*}$ \\
$890-910$ & Is9 & ${ }^{14} \mathrm{C}$ \\
$915-935$ & Is10 & ${ }^{14} \mathrm{C}$ \\
$950-980$ & Is11 & ${ }^{14} \mathrm{C}$ \\
$1010-1055$ & Is12 & ${ }^{14} \mathrm{C}$ \\
$1055-1100$ & H5 & $\delta^{18} \mathrm{O}^{*}$ \\
$1100-1140$ & Is13 & ${ }^{14} \mathrm{C}$ \\
$1155-1200$ & Is14 & ${ }^{14} \mathrm{C}$ \\
\hline
\end{tabular}


617 Table 2:

618 Rapid climatic oscillations identified on core MD01-2472 and corresponding depth. A 619 correlation between isotopic curves (NGRIP-IceCore event, MD-72core-Globigerina 620 bulloides, MD-72core-Uvigerina peregrina) and ${ }^{14} \mathrm{C}$ data have permitted the characterization 621 of these events on core MD01-2472. 


\section{References}

Abad, M., Ruiz, F., Pendón, J.G., Ma Luz González-Regalado, Tosquella, J., 2005. Tortonian ostracodes of Southwestern Europe Ostracodes tortoniens du Sud-Ouest de l'Europe. Geobios 38, 563-573.

Abu-Zied, R.H., Rohling, E.J., Jorissen, F.J., Fontanier, C., Casford, J.S.L., Cooke, S., 2008. Benthic foraminiferal response to changes in bottom-water oxygenation and organic carbon flux in the eastern Mediterranean during LGM to Recent times. Marine Micropaleontology 67 (1-2), 46-68.

Alvarez Zarikian, C.A., Stepanova, A.Y., Grützner, J., 2009. Glacial-interglacial variability in deep sea ostracod assemblage composition at IODP Site U1314 in the subpolar North Atlantic. Marine Geology 258 (1-4), 69-87.

Andreu, B., 1992. Associations d'ostracodes et paléoécologie du Crétacé (Barrémien à Turonien) le long d'une transversale Agadir-Nador (Maroc). Palaeogeography, Palaeoclimatology, Palaeoecology 99 (3-4), 291-319.

Astraldi, M., Gasparini, G.P., 1992. The seasonal characteristics of the circulation in the North Mediterranean basin and their relationship with the atmospheric-climatic conditions. Journal of Geophysical Research 97 (C6), 9531-9540.

Astraldi, M., Gasparini, G.P., 1994. The seasonal characteristics of the circulation in the Tyrrhenian Sea. In La Viollette, P. E., (Ed.), Seasonal and Interannual Variability of the Western Mediterranean Sea, Coastal Estuarine Stud. AGU, Washington, DC, pp. 115-134.

Baringer, M.O., Price, J.F., 1999. A review of the physical oceanography of the Mediterranean outflow. Marine Geology 155, 63-82.

Bard, E., Hamelin, B., Delanghe-Sabatier, D., 2010. Deglacial Meltwater Pulse 1B and Younger Dryas Sea Levels Revisited with Boreholes at Tahiti. Science, 327 (5970): 12351237.

Bassetti, M.A., Carbonel, P., Sierro, F.J., Perez-Folgado, M., Jouët, G., Berné, S., 2010. Response of ostracods to abrupt climate changes in the Western Mediterranean (Gulf of Lions) during the last $30 \mathrm{kyr}$. Marine Micropaleontology 77 (1-2), 1-14.

Bé, A.W.H., Tolderlund, D.S., 1971. Distribution and ecology of living planktonic foraminifera in surface waters of the Atlantic and Indian Oceans. In: Funnel, B.M., Riedel, W.R. (Eds.), Micropaleontology of the Oceans. Riedel, Cambridge University Press, London., pp. 105-149.

Bé, A.W.H., Hutson, W.H., 1977. Ecology of planktonic foraminifera and biogeographic patterns of life and fossil assemblages in the Indian Ocean. Micropaleontology 23 (4), 369414.

Bernhard, J., Sen Gupta, B.K., 1999. Foraminifera of oxygen-depleted environments. In: Sen Gupta, B.K.E. (Ed.), Modern Foraminifera. Kluwer Academic Publishers, pp. 201-216.

Béthoux, J.P., Morin, P., Chaumery, C., Connan, O., Gentili, B., Ruiz-Pino, D., 1998. Nutrients in the Mediterranean Sea, mass balance and statistical analysis of concentrations with respect to environmental change. Marine Chemistry 63 (1-2), 155-169.

Blanc, F., Blanc-Vernet, L., Laurec, A., Le Campion, J., Pastouret, L., 1975. Application paléoécologique de la méthode d'analyse factorielle en composantes principales: interprétation des microfaunes de foraminifères planctoniques quaternaires en méditerranée. II. Étude des espèces de méditerranée orientale. Palaeogeography, Palaeoclimatology, Palaeoecology 18 (4), 293-312.

Bonaduce, G., Ciampo, G., Masoli, M., 1975. Distribution of Ostracoda in the Adriatic Sea. Pubbl. Staz. Zool. Napoli, 40 (1), 1-148. 
Bond, G., Heinrich, H., Broecker, W., Labeyrie, L., Mcmanus, J., Andrews, J., Huon, S., Jantschik, R., Clasen, S., Simet, C., Tedesco, K., Klas, M., Bonani, G., Ivy, S., 1992. Evidence for massive discharges of icebergs into the North Atlantic during the last glacial period. Nature 360, 245-249. Bond, G.C., Broecker, W., Johnsen, S., McManus, J., Labeyrie, L., Jouzel, J., Bonani, G., 1993. Correlations between climate records from North Atlantic sediments and Greenland ice.

Bryden, H.L., Stommel, H.M., 1984. Limiting processes that determine basic features of circulation in the Mediterranean Sea. Oceanology Acta 7, 289-296.

Cacho, I., Grimalt, J.O., Canals, M., 2002. Response of the Western Mediterranean Sea to rapid climatic variability during the last 50,000 years: a molecular biomarker approach. Journal of Marine Systems 33-34, 253-272.

Cacho, I., Shackleton, N., Elderfield, H., Sierro, F.J., Grimalt, J.O., 2006. Glacial rapid variability in deep-water temperature and $\delta 180$ from the Western Mediterranean Sea. Quaternary Science Reviews 25 (23-24), 3294-3311.

Calvès, G., Toucanne, S., Jouet, G., Charrier, S., Thereau, E., Etoubleau, J., Marsset, T., Droz, L., Bez, M., Abreu, V., Jorry, S., Mulder, T., Lericolais, G., 2012. Inferring denudation variations from the sediment record; an example of the last glacial cycle record of the Golo Basin and watershed, East Corsica, western Mediterranean sea. Basin Research 25 (2), 197 218.

Carbonel, P., 1980. Les ostracodes et leur intérêt dans la définition des écosystèmes estuariens et de plate-forme continentale. Essais d'application à des domaines anciens. Bulletin de l'Institut de Géologie du Bassin d'Aquitaine, pp. 1-330.

Caruso, A., Cosentino, C., Pierre, C., Sulli, A., 2011. Sea-level changes during the last 41,000 years in the outer shelf of the southern Tyrrhenian Sea: Evidence from benthic foraminifera and seismostratigraphic analysis. Quaternary International, 232(1-2):122-131.

Ciampo, G., 2004. Ostracods as palaeoenvironmental indicators in the last $30 \mathrm{ky}$ from the Tyrrhenian continental shelf. Global and Planetary Change 40 (1-2), 151-157.

Combourieu-Nebout, N., Peyron, O., Dormoy, I., Desprat, S., Beaudouin, C., Kotthoff, U., Marret, F., 2009. Rapid climatic variability in the west Mediterranean during the last 25,000 years from high resolution pollen data. Climate of the Past 5, 503-521.

Combourieu-Nebout, N., Peyron O., Bout-Roumazeilles, V., Goring, S., Dormoy, I., Joannin, S., Sadori, L., Siani, G., Magny, M. 2013. Holocene vegetation and climate changes in central Mediterranean inferred from a high-resolution marine pollen record (Adriatic Sea). Climate of the Past Discussions, 9: 1969-2014.

Cronin, T.M., 1983. Bathyal ostracodes from Florida-Hatteras Slope, the straits of Florida and the Blake Plateau. Marine Micropaleontology 8, 89-19.

Cronin, T.M., Holtz, J.T.R., Stein, R., Spielhagen, R., Futterer, D., Wollenburg, J., 1995. Late Quaternary paleoceanography of the Eurasian Basin, Artic Ocean. Paleoceanography 10 (2), 259-281.

Cronin, T.M., Raymo, M.E., Kyle, K.P., 1996. Pliocene (3.2-2.4 Ma) ostracode faunal cycles and deep ocean circulation, North Atlantic Ocean. Geology 24 (8), 695-698.

Dansgaard, W., Johnsen, S.J., Clausen, H.B., Dahl-Jensen, N.S., Hammer, C.U., Hvidberg, C.S., Steffensen, J.P., Sveinbjörnsdottir, A.E., Jouzel, J., Bond, G.C., 1993. Evidence for general instability of past climate from a 250-kyr ice-core record. Nature 364, 218-220.

De Rijk, S., Troelstra, S.R., Rohling, E.J., 1999. Benthic foraminiferal distribution in the Mediterranean Sea. Journal of Foraminiferal Research 29 (2), 93-103.

De Rijk, S., Jorissen, F.J., Rohling, E.J., Troelstra, S.R., 2000. Organic flux control on bathymetric zonation of Mediterranean benthic foraminifera. Marine Micropaleontology 40 (3), 151-166. 
De Stigter, H.C., Jorissen, F.J., van der Zwaan, G.J., 1998. Bathymetric distribution and microhabitat partitioning of live (Rose Bengal stained) foraminifera along a shelf to bathyal transect in the southern Adriatic Sea. Journal of Foraminiferal Research 28, 40-65. Di Donato, V., Esposito, P., Garilli, V., Naimo, D., Buccheri, G., Caffau, M., Ciampo, G., Greco, A., Stanzione, D., 2009. Surface-bottom relationships in the Gulf of Salerno (Tyrrhenian Sea) over the last 34 kyr: Compositional data analysis of palaeontological proxies and geochemical evidence. Geobios 42 (5), 561-579.

Dingle, R.V., Lord, A.R., 1990. Benthic ostracods and deep-water in the Atlantic ocean. Palaeogeography, Palaeoclimatology, Palaeoecology 80, 212-235.

El Hmaidi, A., Carbonel, P., Gensous, B., Monaco, A., 1998. Environnements sédimentaires et associations d'ostracodes au Quaternaire terminal sur la pente continentale rhodanienne (Méditerranée occidentale). Geobios 31 (5), 621-631. marqueurs des paléoenvironnements de la marge rhodanienne (Méditerranée occidentale) à la fin duQuaternaire. Newsletters on Stratigraphy 37 (1-2), 3-20.

El Hmaidi, A., El Moumni, B., Nachite, D., Bekkali, R., Gensous, B., 2010. Distribution et de la marge orientale du détroit de Gibraltar (mer d'Alboran, Maroc). Revue de Micropaléontologie 53 (1), 17-28.

Fletcher, W.J., Sánchez Goñi, M.F., 2008. Orbital- and sub-orbital-scale climate impacts on vegetation of the western Mediterranean basin over the last 48,000 yr. Quaternary Research 70 (3), 451-464.

Fontanier, C., Jorissen, F.J., Chaillou, G., David, C., Anschutz, P., Lafon, V., 2003. Seasonal and interannual variability of benthic foraminiferal faunas at $550 \mathrm{~m}$ depth in the Bay of Biscay. Deep Sea Research Part I: Oceanographic Research Papers 50 (4), 457-494.

Fontanier, C., Mackensen, A., Jorissen, F.J., Anschutz, P., Licari, L., Griveaud, C., 2006. Stable oxygen and carbon isotopes of live benthic foraminifera from the Bay of Biscay: Microhabitat impact and seasonal variability. Marine Micropaleontology 58 (3), 159-183. Fontanier, C., Jorissen, F.J., Lansard, B., Mouret, A., Buscail, R., Schmidt, S., Kerhervé, P., Buron, F., Zaragosi, S., Hunault, G., Ernoult, E., Artero, C., Anschutz, P., Rabouille, C., 2008. Live foraminifera from the open slope between Grand Rhône and Petit Rhône Canyons (Gulf of Lions, NW Mediterranean). Deep Sea Research Part I: Oceanographic Research Papers 55 (11), 1532-1553.

Frigola, J., Moreno, A., Cacho, I., Canals, M., Sierro, F.J., Flores, J.A., Grimalt, J.O., Hodell, D.A., Curtis, J.H., 2007. Holocene variability in the western Mediterranean region from a deepwater record. Paleoceanography 22 (2), PA2209.

Frigola, J., Moreno, A., Cacho, I., Canals, M., Sierro, F.J., Flores, J.A., Grimalt, J.O., 2008. Evidence of abrupt changes in Western Mediterranean Deep Water circulation during the last 50 kyr: A high-resolution marine record from the Balearic Sea. Quaternary International 181 (1), 88-104.

Ganopolski, A., Rahmstorf, S., 2001. Rapid changes of glacial climate simulated in a coupled climate model. Nature 409 (6817), 153-158.

Gonthier E., Faugères J.-C., Stow, D.A.V., 1984. Contourite facies of the Faroe drift, Gulf of Cadiz. In: Stow, D.A.V. \& Piper, D.J.W. (Eds.) Fine-Grained Sediments: Deep-Water Processes and Facies. Geological Society, London, pp. 275-292.

Gooday, A.J., 2003. Benthic foraminifera (protista) as tools in deep-water palaeoceanography: Environmental influences on faunal characteristics. Advances in Marine Biology. Academic Press, pp. 1-90. 
Hajjaji, M., Bodergat, A.-M., Moissette, P., Prieur, A., Rio, M., 1998. Signification écologique des associations d'ostracodes de la coupe de Kritika (Pliocène supérieur, Rhodes, Grèce). Revue de Micropaléontologie 41 (3), 211-233. Hammer, Ø., Harper, D.A.T., Ryan, P.D., 2001. PAST: Paleontological Statistics Software Package for Education and Data Analysis. Palaeontologia Electronica 4(1), 9pp. http://palaeoelectronica.org/2001 1/past/issue1 01.htm.

Harloff, J., Mackensen, A., 1997. Recent benthic foraminiferal associations and ecology of

Hayes, A., Rohling, E.J., De Rijk, S., Kroon, D., Zachariasse, W.J., 1999. Mediterranean planktonic foraminiferal faunas during the last glacial cycle. Marine Geology 153 (1-4), 239252.

Hemleben, C., Spindler, M., Anderson, O.R., 1989. Modern Plantonic Foraminifera. Springer, New York, 363 pp.

Johannessen, T., Jansen, E., Flatøy, A., Ravelo, A.C., 1994. The relationship between surface water masses, oceanographic fronts and paleoclimatic proxies in surface sediments of the Greenland, Iceland, Norwegian Seas. NATO ASI Ser. I, 61-86.

Jorissen, F.J., 1999. Benthic foraminiferal successions across Late Quaternary Mediterranean sapropels. Marine Geology 153 (1-4), 91-101.

Jorissen, F.J., Wittling, I., 1999. Ecological evidence from live-dead comparisons of benthic foraminiferal faunas off Cape Blanc (Northwest Africa). Palaeogeography, Palaeoclimatology, Palaeoecology 149 (1-4), 151-170.

Kinder, T.H., Parrilla, G., 1987. Yes, some of the Mediterranean outflow does come from great depth. Journal of Geophysical Research: Oceans 92 (C3), 2901-2906.

Kotthoff, U., Müller, U.C., Pross, J., Schmiedl, G., Lawson, I.T., van de Schootbrugge, B., Schulz, H., 2008. Lateglacial and Holocene vegetation dynamics in the Aegean region: an integrated view based on pollen data from marine and terrestrial archives. The Holocene 18 (7), 1019-1032.

Kroon, D., 1991. Distribution of extant planktic foraminiferal assemblages in Red Sea and Northern Indian Ocean surface waters. Rev. Esp. Micropaleontol. 23, 37-74.

Lambeck, K., Antonioli, F., Anzidei, M., Ferranti, L., Leoni, G., Scicchitano, G., Silenzi, S., 2011. Sea level change along the Italian coast during the Holocene and projections for the future. Quaternary International, 232 (1-2):250-257.

La Violette, P.E.E., 1994. Seasonal and Interannual Variability of the Western Mediterranean Sea. Coastal Estuarine Stud., 46. AGU, Washington, DC, 374 pp.

Löwemark, L., Schönfeld, J., Werner, F., Schäfer, P., 2004. Trace fossils as a paleoceanographic tool: Evidence from Late Quaternary sediments of the southwestern Iberian margin. Marine Geology 204 (1-2), 27-41.

Mackensen, A., Fütterer, D.K., Grobe, H., Schmiedl, G., 1993. Benthic foraminiferal assemblages from the eastern South Atlantic Polar Front region between 35 and $57^{\circ} \mathrm{S}$ : Distribution, ecology and fossilization potential. Marine Micropaleontology 22, 33-69.

Magny M., Combourieu Nebout N., de Beaulieu, J. L., Bout-Roumazeilles, V., Colombaroli D., Desprat, S., Francke, A., Joannin, S., Peyron, O., Revel, M., Sadori, L., Siani, G., Sicre, M. A., Samartin, S., Simonneau, A., Tinner, W., Vannière, B., Wagner, B., Zanchetta, G., Anselmetti, F., Brugiapaglia, E., Chapron E., Debret, M., Desmet, M., Didier, J., Essallami, L., Galop, D., Gilli, A., Haas, J.N., Kallel, N., Millet, L., Stock A., Turon, J. L., Wirth, S., 2013. North-south palaeohydrological contrasts in the central Mediterranean during the Holocene: tentative synthesis and working hypotheses. Climate of the Past Discussions, 9: 1901-1967

Mayewski, P.A., Rohling, E.E., Stager, C.J., Karlén, W., Maasch, K.A., Meeker, D.L., Meyerson, E.A., Gasse, F., Shirley van K., Holmgren, K., Lee-Thorp, J., Rosqvist, G., Rack, 
F., Staubwasser, M., Schneider, R.R., Steig, E.J., 2004. Holocene climate variability. Quaternary Research 62 (3), 243-255.

McCave, I.N., Hall, I.R., 2006. Size sorting in marine muds: Processes, pitfalls, and prospects for paleoflow-speed proxies. Geochem. Geophys. Geosyst. 7 (10), Q10N05.

McCave, I.N., Manighetti, B., Robinson, S.G., 1995. Sortable silt and fine sediment size/composition slicing: Parameters for palaeocurrent speed and palaeoceanography. Paleoceanography 10, 593-610. Mayewski, P.A., Bolzan, J.F., 1997. The Greenland Ice Sheet Project 2 depth-age scale: Methods and results. Journal of Geophysical Research: Oceans 102 (C12), 26411-26423.

Melki, T., Kallel, N., Jorissen, F.J., Guichard, F., Dennielou, B., Berné, S., Labeyrie, L., Fontugne, M., 2009. Abrupt climate change, sea surface salinity and paleoproductivity in the western Mediterranean Sea (Gulf of Lion) during the last $28 \mathrm{kyr}$. Palaeogeography, Palaeoclimatology, Palaeoecology 279 (1-2), 96-113.

Migeon, S., Weber, O., Faugeres, J.-C., Saint-Paul, J., 1999. SCOPIX: a new imaging system for core analysis. GeoMarine Letters 18, 251-255.

Mikolajewicz, U., 2011. Modeling Mediterranean Ocean climate of the Last Glacial Maximum. Climate of the Past, 7: 161-180.

Milker, Y., Schmiedl, G., 2012. A taxonomic guide to modern benthic shelf foraminifera of the western Mediterranean Sea. Palaeontologia Electronica 15 (2), 134p.

Millot, C., 1999. Circulation in the Western Mediterranean Sea. Journal of Marine Systems 20, 423-442.

Mojtahid, M., Jorissen, F., Lansard, B., Fontanier, C., Bombled, B., Rabouille, C., 2009. Spatial distribution of live benthic foraminifera in the Rhône prodelta: Faunal response to a continental-marine organic matter gradient. Marine Micropaleontology 70 (3-4), 177-200.

Moreno, A., Cacho, I., Canals, M., Grimalt, J.O., Sánchez-Goñi, M.F., Shackleton, N., Sierro, F.J., 2005. Links between marine and atmospheric processes oscillating on a millennial timescale. A multi-proxy study of the last 50,000 yr from the Alboran Sea (Western Mediterranean Sea). Quaternary Science Reviews 24 (14-15), 1623-1636.

Morigi, C., Jorissen, F.J., Gervais, A., Guichard, S., Borsetti, A.M., 2001. Benthic foraminiferal faunas in surface sediments off NW Africa: relationship with organic flux to the ocean floor. Journal of Foraminiferal Research 31 (4), 350-368.

Morigi, C., Jorissen, F.J., Fraticelli, S., Horton, B.P., Principi, M., Sabbatini, A., Capotondi, L., Curzi, P.V., Negri, A., 2005. Benthic foraminiferal evidence for the formation of the Holocene mud-belt and bathymetrical evolution in the central Adriatic Sea. Marine Micropaleontology 57 (1-2), 25-49.

Nachite, D., Rodríguez-Lázaro, J., Martín-Rubio, M., Pascual, A., Bekkali, R., 2010. Distribution et écologie des associations d'ostracodes récents de l'estuaire de Tahadart (Maroc Nord-Occidental). Revue de Micropaléontologie 53 (1), 3-15.

Nebout, N.C., Turon, J.L., Zahn, R., Capotondi, L., Londeix, L., Pahnke, K., 2002. Enhanced aridity and atmospheric high-pressure stability over the western Mediterranean during the North Atlantic cold events of the past 50 k.y. Geology 30 (10), 863-866.

Parker, F.L., 1971. Distribution of planktonic foraminifera in Recent deep-sea sediments. In: Funnell, B.M., Riedel, W.R. (Eds.), The Micropaleontology of the Oceans. Cambridge University Press, Cambridge, pp.289-307.

Passlow, V., 1994. Late Quaternary history of the Southern Ocean Offshore southeastern Australia, based on Ostracoda. Thesis, Australian National University, Camberra.

Paterne, M., Kallel, N., Labeyrie, L., Vautravers, M., Duplessy, J.-C., Rossignol-Strick, M., Cortijo, E., Arnold, M., Fontugne, M., 1999. Hydrological relationship between the North 
Atlantic Ocean and the Mediterranean Sea during the past 15-75 kyr. Paleoceanography 14 872 (5), 626-638.

873 Pérez-Folgado, M., Sierro, F.J., Flores, J.A., Cacho, I., Grimalt, J.O., Zahn, R., Shackleton, 874 N., 2003. Western Mediterranean planktonic foraminifera events and millennial climatic variability during the last 70 kyr. Marine Micropaleontology 48 (1-2), 49-70.

Pérez-Folgado, M., Sierro, F.J., Flores, J.A., Grimalt, J.O., Zahn, R., 2004. Paleoclimatic variations in foraminifer assemblages from the Alboran Sea (Western Mediterranean) during the last $150 \mathrm{ka}$ in ODP Site 977. Marine Geology 212 (1-4), 113-131.

Peypouquet, J.P., 1979. Ostracodes et paléoenvironnements. Méthodologie et application aux domaine profonds du Cénozoique. Bulletin B.R.G.M. 2nd Ser. (Sect. 4), 3-79.

Peypouquet, J.P., Nachite, D. (Eds.), 1984. Les Ostracodes en Mediterranée occidentale. Ecologie des microorganismes en Mediterranée occidentale "ECOMED". Association Française des Techniciens du Petrole, Paris, 151-169.

Peyron, O., Magny, M., Goring, S., Joannin, S., de Beaulieu, J.-L., Brugiapaglia, E., Sadori, L., Garfi, G., Kouli, K., Loakim, C., Combourieu-Nebout, N., 2012. Contrasting patterns of climatic changes during the Holocene in the Central Mediterranean (Italy) reconstructed from pollen data. Climate of the Past Discussions 8 (6), 5817-5866.

Pinardi, N., Masetti, E., 2000. Variability of the large scale general circulation of the Mediterranean Sea from observations and modelling: a review. Palaeogeography Paleoclimatology paleoecology 158, 153-173.

Rasmussen, T.L., Thomsen, E., Troelstra, S.R., Kuijpers, A., Prins, M.A., 2003. Millennialscale glacial variability versus Holocene stability: changes in planktic and benthic foraminifera faunas and ocean circulation in the North Atlantic during the last 60000 years. Marine Micropaleontology 47, 143-176.

Reimer, P.J., Baillie, M.G.L., Bard, E., Bayliss, A., Beck, J.W., Blackwell, P.G., Bronk Ramsey, C., Buck, C.E., Burr, G.S., Edwards, R.L., Friedrich, M., Grootes, P.M., Guilderson, T.P., Hajdas, I., Heaton, T.J., Hogg, A.G., Hughen, K.A., Kaiser, K.F., Kromer, B., McCormac, F.G., Manning, S.W., Reimer, R.W., Richards, D.A., Southon, J.R., Talamo, S., Turney, C.S.M., van der Plicht, J., Weyhenmeyer, C.E., 2009. IntCal09 and Marine09 radiocarbon age calibration curves, 0-50,000 years cal BP Radiocarbon 51 (4), 1111-1150.

Rivière, A., 1977. Méthodes granulo-métriques, techniques et interprétation. Masson, Paris, 170 pp..

Rogerson, M., Rohling, E.J., Bigg, G.R., Ramirez, J., 2012. Paleoceanography of the AtlanticMediterranean exchange: overview and first quantitative assessment of climatic forcing. Review of Geophysics 50, 1-32.

Rohling, E.J., De Rijk, S., 1999. Holocene Climate Optimum and Last Glacial Maximum in the Mediterranean: the marine oxygen isotope record. Marine Geology 153 (1-4), 57-75.

Rohling, E.J., Gieskes, W.W.C., 1989. Late Quaternary changes in Mediterranean intermediate water density and formation rate. Paleoceanography 4 (5), 531-545.

Rohling, E.J., Hayes, A., De Rijk, S., Kroon, D., Zachariasse, W.J., Eisma, D., 1998. Abrupt Cold Spells in the Northwest Mediterranean. Paleoceanography 13 (4), 316-322.

Rohling, E.J., Mayewski, P.A., Abu-Zied, R.H., Casford, J.S.L., Hayes, A., 2002. Holocene atmosphere-ocean interactions: records from Greenland and the Aegean Sea. Climate Dynamics 18, 587-593.

Ruiz, F., González-Regalado, M.L., Muñoz, J.M., 1997. Multivariate analysis applied to total and living fauna: seasonal ecology of recent benthic Ostracoda off the North Cádiz Gulf coast (southwestern Spain). Marine Micropaleontology 31 (3-4), 183-203.

Sadori, L., Ortu, E., Peyron, O., Zanchetta, G., Vannière, B., Desmet, M., Magny, M., 2013. The last 7 millennia of vegetation and climate changes at Lago di Pergusa (central Sicily, Italy). Climate of the Past Discussions 9, 2059-2094, 
Sánchez Goñi, M.F., Turon, J.-L., Eynaud, F., Gendreau, S., 2000. European Climatic Response to Millennial-Scale Changes in the Atmosphere-Ocean System during the Last Glacial Period. Quaternary Research 54 (3), 394-403.

Sánchez Goñi, M.F., Cacho, I., Turon, J., Guiot, J., Sierro, F., Peypouquet, J., Grimalt, J., Shackleton, N., 2002. Synchroneity between marine and terrestrial responses to millennial scale climatic variability during the last glacial period in the Mediterranean region. Climate Dynamics 19 (1), 95-105. Contrasting ima., Landais, A., Fletcher, W.J., Naughton, F., Desprat, S., Duprat, J., 2008. Contrasting impacts of Dansgaard-Oeschger events over a western European latitudinal transect modulated by orbital parameters. Quaternary Science Reviews 27 (11-12), 11361151.

Schmiedl, G., Mackensen, A., 1997. Late Quaternary paleoproductivity and deep water circulation in the eastern South Atlantic Ocean: Evidence from benthic foraminifera. Palaeogeography, Palaeoclimatology, Palaeoecology 130 (1-4), 43-80.

Schmiedl, G., Mackensen, A., Müller, P.J., 1997. Recent benthic foraminifera from the eastern South Atlantic Ocean: Dependence on food supply and water masses. Marine Micropaleontology 32 (3-4), 249-287.

Schmiedl, G., Mitschele, A., Beck, S., Emeis, K.-C., Hemleben, C., Schulz, H., Sperling, M., Weldeab, S., 2003. Benthic foraminiferal record of ecosystem variability in the eastern Mediterranean Sea during times of sapropel S5 and S6 deposition. Palaeogeography, Palaeoclimatology, Palaeoecology 190 (0), 139-164.

Schmiedl, G., Pfeilsticker, M., Hemleben, C., Mackensen, A., 2004. Environmental and biological effects on the stable isotope composition of recent deep-sea benthic foraminifera from the western Mediterranean Sea. Marine Micropaleontology 51 (1-2), 129-152.

Schmiedl, G., Kuhnt, T., Ehrmann, W., Emeis, K.-C., Hamann, Y., Kotthoff, U., Dulski, P., Pross, J., 2010. Climatic forcing of eastern Mediterranean deep-water formation and benthic ecosystems during the past 22000 years. Quaternary Science Reviews 29 (23-24), 3006-3020. Siani, G., Paterne, M., Michel, E., Sulpizio, R., Sbrana, A., Arnold, M., Haddad G., 2001. Mediterranean sea surface radiocarbon reservoir age changes since the last glacial maximum. Science 294: 1917-1920.

Sicre, M.A., Siani, G., Genty, D., Kallel, N., Essallami, L., 2013. Seemingly divergent sea surface temperature proxy records in the central Mediterranean during the last deglacial. Climate of the Past 9 (2), 1375-1383.

Sierro, F.J., Flores, J.A., Baraza, J., 1999. Late glacial to recent paleoenvironmental changes in the Gulf of Cadiz and formation of sandy contourite layers. Marine Geology 155 (1-2), 157-172.

Sierro, F.J., Hodell, D.A., Curtis, J.H., Flores, J.A., Reguera, I., Colmenero-Hidalgo, E., Barcena, M.A., Grimalt, J.O., Cacho, I., Frigola, J., Canals, M., 2005. Impact of iceberg melting on Mediterranean thermohaline circulation during Heinrich events. Paleoceanography 20 (PA2019).

Sierro, F.J., Andersen, N., Bassetti, M.A., Berné, S., Canals, M., Curtis, J.H., Dennielou, B., Flores, J.A., Frigola, J., Gonzalez-Mora, B., Grimalt, J.O., Hodell, D.A., Jouet, G., PérezFolgado, M., Schneider, R., 2009. Phase relationship between sea level and abrupt climate change. Quaternary Science Reviews 28 (25-26), 2867-2881.

Smedile, A., De Martini, P.M., Pantosti, D., Bellucci, L., Del Carlo, P., Gasperini, L., Pirrotta, C., Polonia, A., Boschi, E., 2011. Possible tsunami signatures from an integrated study in the Augusta Bay offshore (Eastern Sicily-Italy). Marine Geology 281 (1-4), 1-13.

Stow, D.A.V., Faugères, J.-C., Gonthier, E., 1986. Facies distribution and textural variation in Faro Drift contourites: Velocity fluctuation and drift growth. Marine Geology 72 (1-2), 71100. 
971 Stow, D.A.V., Reading H.G., Collinson, J.D., 1996. Deep Seas., In: Reading H.G. (Ed.) 972 Sedimentary Environments (3rd Ed.). Blackwell Science, Oxford, pp. 395-454.

973 Toucanne, S., Mulder, T., Schönfeld, J., Hanquiez, V., Gonthier, E., Duprat, J., Cremer, M., 974 Zaragosi, S., 2007. Contourites of the Gulf of Cadiz: A high-resolution record of the 975 paleocirculation of the Mediterranean outflow water during the last 50,000 years. 976 Palaeogeography, Palaeoclimatology, Palaeoecology 246 (2-4), 354-366.

977 Toucanne, S., Jouet, G.1., Ducassou, E., Bassetti, M.-A., Dennielou, B., Angue Minto'o, C.M., 978 Lahmi, M., Touyet, N., Charlier, K., Lericolais, G., Mulder, T., 2012. A 130,000-year record 979 of Levantine Intermediate Water flow variability in the Corsica Trough, western 980 Mediterranean Sea. Quaternary Science Reviews 33, 55-73.

981 Vignudelli, S., Cipollini, P., Astraldi, M., Gasparini, G.P., Manzella, G., 2000. Integrated use 982 of altimeter and in situ data for understanding the water exchanges between the Tyrrhenian 983 and Ligurian Seas. Journal of Geophysical Research 105 (C8), 19649-19663.

984 Voelker, A.H.L., Lebreiro, S.M., Schönfeld, J., Cacho, I., Erlenkeuser, H., Abrantes, F., 2006. 985 Mediterranean outflow strengthening during northern hemisphere coolings: A salt source for 986 the glacial Atlantic? Earth and Planetary Science Letters 245 (1-2), 39-55.

987 Wang, L., Sarnthein, M., 1999. Long-/short-term variations of monsoon climate and its 988 teleconnection to global change: high resolution grain size records of siliciclastic sediments 989 from the South China Sea. In: Abrantes, F., Mix, A.C. (Eds.), Reconstructing Ocean History: 990 A Window into the Future. Plenum, New York, pp. 57-72.

991 Wu, P., Haines, K., 1996. Modeling the dispersal of Levantine Intermediate Water and its role 992 in Mediterranean deep water formation. J. Geophys. Res. 101 (C3), 6591-6607.

993 Zaragosi, S., Bourillet, J.-F., Eynaud, F., Denhard, B., Van Toer, A., Lanfumey, V., 2006. The 994 impact of the last European deglaciation on the Bay of Biscay turbidite systems. Geo-Marine 995 Letters 26 (6), 317-330.

996 Zhou, B., Zhao, Q., 1999. Allochthonous ostracods in the South China Sea and their 997 significance in indicating downslope sediment contamination. Marine Geology 156 (1-4), 998 187-195. 
Appendix A: Taxonomy list of benthic foraminifers identified in core MD01-2472

Ammonia sp.

Ammonia ammoniformis

Ammonia beccarii

Cushman, 1926; Brünnich, 1772; d'Orbigny, 1846

Melonis barleeanus

Amphicoryna scalaris

Batsch, 1791

Asterigerinata mamilla

Williamson, 1848

Bigenerina nodosaria

d'Orbigny, 1826

Biloculinella globula

Bornemann, 1855

Bolivina alata

Seguenza, 1862

Williamson 1858

Miliolinella sp.

Wiesner, 1931

Nonion asterizans

Fichtel \& Moll, 1798

Nonionella turgida

Williamson, 1858

Planulina ariminensis

d'Orbigny, 1826

Polymorphinella sp.

Bolivina sp.

Bolivina spathulata

Bolivina striatula

Bolivina subaenariensis

d'Orbigny, 1843; Williamson, 1858; Cushman, 1922

Cushman \& Hanzawa, 1936

Bulimina acuealta

Bulimina costata

Bulimina elegans

Bulimina elongata

Bulimina marginata

d'Orbigy, 1826, 1852, 1884

Cancris auriculus

Fichtel and Moll 1798

Cassidulina carinata

Cassidulina minuta

Silvestri, 1896; Cushman, 1933

Cassidulinoides bradyi

Norman, 1881

Chilostomella $\mathrm{sp.}$

Reuss, 1849

Cibicidoides bradyi

Cibicidoides sp.

Cibicidoides lobatulus

Cibicidoides pachyderma

Cibicidoides wuellerstorfi

Walker and Jacob 1798; de Montfort, 1808 ; Schwager Robertina translucens

1866 ; d'Orbigny, 1896; Trauth, 1918 ;

Cyclogyra sp.

Schultze, 1854

Cushman \& Parker, 1936

Pseudoclavulina crustata

Cushman, 1936

Pullenia quinqueloba

Reuss, 1851

Pyrgo sp.

Pyrgo murrhina

Defrance, 1824 ; Schwager 1866

Quinqueloculina sp.

d'Orbigny, 1826

Rectobolivina $\mathrm{sp}$.

Cushman, 1927

Rectuvigerina phlegeri

Le Calvez, 1958

Dentalina sp.

Dentalina guttifera

d'Orbigny, 1826 ; 1846

Robulus sp.

de Montfort, 1808

Elphidium sp.

Elphidium aculeatum

Elphidium complanatum

Elphidium macellum

Fichtel \& Moll, 1798; de Montfort, 1808 ; d'Orbigny, Sigmoilina tenuis

1846,1839

Rosalina globularis

d'Orbigny, 1826

Fissurina sp.

Fissurina apiculata

Fissurina cucullata

Reuss, 1850 ; Silvestri, 1902 ; Sidebottom, 1912

Czjek, 1848

Fursenkoina complanata

Sigmoilopsis schlumbergeri

Silvestri 1904

Siphonina reticulata 
Egger, 1893

Globulimina affinis

D’Orbigny 1839

Gyroidina altiformis

R.E. \& K.C. Stewart, 1930

Hoeglundina elegans

d'Orbigny 1826

Hyalinea balthica

Schröter, 1783

Islandiella islandica

Norvang, 1945

Lagena sp.

Lagena hexagona

Lagena striata

Lagena sulcata

Walker \& Boys, 1784; Walker \& Jacob, 1798; Triloculina sp.

d'Orbigny, 1839 ; Williamson, 1848

Lagenosolenia sigmoidella

Cushman \& Gray, 1946

Lenticulina sp.

Lamarck, 1804

Massilina secans

d'Orbigny, 1826
Czjzek, 1884

Spiroloculina sp.

d'Orbigny, 1826

Spirophthalmidium sp.

Cushman, 1927

Suggrunda eckisi

Natland, 1950

Textularia sp.

Defrance, 1824

Trifarina angulosa

Williamson, 1858

d'Orbigny, 1826

Uvigerina auberiana

Uvigerina bifurcata

Uvigerina mediterranea

Uvigerina peregrina

Cushman, 1923; Hofker, 1932 ; d'Orbigy, 1839

Valvulineria bradyana

Fornasini, 1900 
Appendix B: taxonomy list of ostracods identified in core MD01-2472

\author{
Argilloecia acuminata \\ Müller, 1894 \\ Aurila sp. \\ Pokorny, 1955 \\ Bairdia sp. \\ Mccoy, 1844
}

Bathycythere vanstraateni

Sissingh, 1971

Bosquetina dentata

Müller, 1894

Buntonia sp.

Howe \& Chambers, 1935

Bythocypris sp.

Brady, 1880

Bythocythere constricta

Sars, 1866

Callistocythere sp.

Ruggieri, 1953

Carinocythereis carinata

Roemer, 1838

Costa sp.

Neviani, 1928

Cyprideis sp.

Jones, 1856

Cytherella lata

Brady, 1880

Cytheropteron alatum

Sars, 1866

Cytheropteron monoceros

Cytheropteron zinzulusae

Bonaduce, Ciampo \& Masoli, 1976

Cytheropteron nodosum

Brady, 1868

Cytheropteron testudo

Sars, 1869

Echinocythereis echinata

Sars, 1866

Eucythere sp.

Brady, 1868

Hemicytherura videns

Müller, 1894

Henryhowella sp.

Puri, 1957

Heterocythereis albomaculata

Baird, 1838

Hiltermannicythere turbida

Müller, 1894

Krithe sp.

Brady in Crosskey \& Robertson, 1874

Krithe compressa

Seguenza, 1980
Krithe keyi

Breman, 1978

Krithe pernoides

Bornemann, 1855

Leptocythere sp.

Müller, 1927

Loxoconcha levis

Loxoconcha minima

Loxoconcha sp.

Müller, 1894

Macrocypris sp.

Brady, 1868

Monoceratina mediterranea

Sissingh, 1971

Muellerina sp.

Bassiouni, 1965

Paracypris sp.

Sars, 1866

Paradoxostoma sp.

Fischer, 1855

Parakrithe sp.

Bold, 1958

Pedicythere polita

Colalongo \& Pasini, 1980

Pedicythere tessellata

Bonaduce, Ciampo \& Masoli, 1976

Phlyctocythere sp.

Key, 1958

Polycope sp.

Sars, 1866

Pontocythere sp.

Dubovsky, 1939

Propontocypris sp.

Sylvester-Bradley, 1947

Pseudocythere caudata

Sars, 1866

Pseudocytherura calcarata

Seguenza, 1880

Pterygocythereis jonesii

Baird, 1850

Sagmatocythere sp.

Athersuch, 1976

Semicytherura sp.

Wagner, 1957

Thaerocythere sp.

Hazel, 1967

Urocythereis favosa

Roemer, 1838

Xestoleberis sp. Sars, 1866 


\section{Appendix C: Ecological significance of planktonic/benthic foraminifers and ostracods species}

1. Ecological significance of planktonic foraminifers: Neogloboquadrina pachyderma and Turborotalita quinqueloba

- Neogloboquadrina pachyderma S: Cold sea surface temperature indicator:

N. pachyderma $\mathrm{S}$ indicates the coolest sea surface conditions. It strongly dominates planktonic foraminiferal assemblages in polar areas (Bé and Tolderlund, 1971; Bandy, 1972; Cifelli, 1973) at temperatures below $7-9^{\circ} \mathrm{C}$ (Bé and Tolderlund, 1971; Bé and Hutson, 1977; Reynolds and Thunell, 1986). It has also been found living in seasonal sea ice (Spindler, 1990; Serrano and Guerra-Merchán, 2012). The presence of $N$. pachyderma $\mathrm{S}$ in the Mediterranean Sea during the middle Quaternary is thought to be related to the entry of cold waters carrying these forms from the North Atlantic (Sierro et al., 2005; Serrano and GuerraMerchán, 2012).

- Turborotalia quinqueloba: high surface primary productivity indicator:

Turborotalia quinqueloba is a subpolar species that rapidly responds to changes in nutrient supply (Reynolds and Thunell, 1985). It is often related to upwelling or oceanic fronts (Parker, 1971; Hemleben et al., 1989; Kroon, 1991; Johannessen et al., 1994) and thus considered as an indicator of high surface productivity (Rasmussen et al., 2003)

\section{Ecological significance of benthic foraminifers}

- Cluster 1: Uvigerina mediterranea and Melonis barleeanus; oligo-mesotrophic bottom conditions

U. mediterranea and M. barleeanus appear more abundant during Holocene period (with a percentage up to 50\%) than during MIS 2 and MIS3.

U. mediterranea is a shallow infaunal species (Corliss, 1985; Corliss and Emerson, 1990; Gooday, 1994; Jorissen et al., 1998) and is regarded as feeding on labile organic matter in well-oxygenated microhabitats with a low tolerance to dysoxic conditions (Lutze and Coulbourn, 1984; Corliss, 1985; Schmiedl et al., 2000).

M. barleeanus is an intermediate infaunal species that seems to be adapted to the presence of refractory organic matter (Fontanier et al., 2002) and occurs slightly deeper in the sediment in a zone of nitrate reduction (Jorissen et al., 1998). 
- Cluster 2: Bigenerina nodosaria, Textularia sp., Chilostomella sp. and Pseudoclavulina crustata; oxygenation drop conditions

Cluster 2 shows abundance maxima in MIS 1 and it is composed of the following species:

Chilostomella species are deep infaunal taxon and are commonly found in oxygendepleted and organically-enriched environments (Bernhard and Sen Gupta, 1999; Jorissen 1999b, Schmiedl et al., 2003). Bigenerina nodosaria is found under the same environmental conditions and is typical of intermediate platforms but its extension in bathyal environments can be associated with fine-grained sediment (Alves Martins and Dragao Gomes, 2004).

Textularia sp. is also part of the infauna taxa and is associated with fine-grained sediment (Haunold et al., 1997).

Very little is known concerning the ecological requirements of Pseudoclavulina crustata, thus we are not able to relate its occurrence to particular environmental conditions. However, we observe its presence only in MIS 1.

- Cluster 3a: Hyalinea balthica and Bolivina spathulata; meso-eutrophic bottom conditions

In cluster $3 \mathrm{a}, H$. balthica and $B$. spathulata are very abundant (10\% to 50\%) in MIS 2 and MIS 3 (from 56,000 y to 11,800 y BP) and show a significant decrease in MIS 1 (from $11,800 \mathrm{y}$ to present), as illustrated in Fig 7.

Hyalinea balthica is essentially a neritic and epibathyal species (Parker, 1958) found in several environments. It is recorded in the Atlantic, Pacific, and Indian Oceans, the Gulf of Mexico, and the Caribbean, Barents, North, and Mediterranean Seas. In the modern ocean, $H$. balthica is most abundant in cooler waters of the North Atlantic (van Morkhoven et al., 1986). It has a preference for shallow infaunal microhabitats in the topmost sediment levels, where high densities are found (Fontanier et al., 2002; Hess and Jorissen, 2009). Ross (1984) put in evidence the presence of $H$. balthica in the Sicily Strait both during glacial and interglacial phases, with a considerable decrease in abundance during the Holocene. Morigi et al. (2001) and Abu-Zied et al. (2008) describe H. balthica as a component of eutrophic and relatively well-oxygenated water assemblage. 
Bolivina spathulata prefers a shallow to intermediate infaunal microhabitat (Corliss, 1991; Barmawidjaja et al., 1992; De Stigter et al., 1998). In the modern Mediterranean Sea, $B$. spathulata is part of a species group that commonly occurs in a wide range of mesotrophic to eutrophic settings (Barmawidjaja et al., 1992; Jorissen et al., 1995; De Stigter et al., 1998; De Rijk et al., 2000; Schmiedl et al., 2000; Mojtahid et al., 2009).

- Cluster 3b: Bulimina marginata, Bulimina costata and Gyroidina altiformis; meso-eutrophic bottom conditions

Bulimina marginata, B. costata and G. altiformis are abundant from 56,000 to 11,800 y BP: in MIS 2, MIS 3 and Termination I with a percentage reaching 30\%. From 11,800 y to recent (MIS 1), they show a diminution of abundance (Fig. 7).

Bulimina marginata is an opportunistic species inhabiting shallow infauna microhabitats with high organic input associated with nutrient-rich waters (Abu-Zied et al., 2008; Frezza and Carboni, 2009).

Jorissen (1999b), considers B. costata as one of the most tolerant species to low oxygen content in sediments, but bottom water oxygenation seems not to be the only parameter controlling the abundance of this species. The intensity of organic carbon flux (food) is thought to be responsible for B. costata distribution (Schmiedl et al., 1997; Schmiedl et al., 2000; Rogerson et al., 2006).

Gyroidina altiformis is considered as a mesotrophic-oligotrophic benthic foraminifer (De Rijk et al., 2000; Fontanier et al., 2002).

- Cluster 3c: Cibicidoides wuellerstorfi, Cassidulina carinata, Quinqueloculina sp., Trifarina angulosa, Hoeglundina elegans, Cibicidoides Pachyderma; well oxygenated bottom conditions

Cibicidoides wuellerstorfi, C. carinata, T. angulosa, C. pachyderma, H. elegans, and Quinqueloculina are more abundant in MIS 2 and 3, with a global percentage comprised between $10 \%$ and $40 \%$, compared to MIS 1 where they strongly decrease $(5-11 \%$; Fig. 7$)$

Cibicidoides wuellerstorfi is an epifaunal species (Lutze and Thiel, 1989), typical of highly oxygenated environments and a fluctuating input of organic matter. This epifaunal taxon is also able to develop in environment where bottom water oxygenation values indicate hypoxic conditions (Rathburn and Corliss, 1994; Jorissen et al., 2007) 
Cassidulina carinata can be considered as opportunistic and is observed in ecosystems with an intermittent supply of organic matter to the sea floor (Abu-Zied et al., 2008; Frezza and Carboni, 2009). Hayward et al. (2002) have shown that C. carinata and T. angulosa are part of a shallow water association, occurring within coarse substrates under well-oxygenated, high energy regimes and sustained food input.

Trifarina angulosa is a shallow infaunal species (Cacho et al., 2001; Schönfeld, 2001; De Stigter et al., 1998) and occurs in low to moderate abundances from subtidal to middle bathyal depths (Lutze, 1980; Jorissen, 1988). T. angulosa is adapted to strong water turbulence of varying intensity and might indicate strong bottom currents (Mackensen et al., 1993; Harloff and Mackensen, 1997).

In the Mediterranean Sea, the distribution of C. pachyderma is associated with oligotrophic to mesotrophic and well-ventilated conditions (Schmiedl et al., 2000). It is a bathyal species which often shows a decrease in the Mediterranean during deglacial periods (Alves Martins and Dragao Gomes, 2004).

Hoeglundina elegans has mainly shallow infaunal microhabitat. It is found in welloxygenated environments (Corliss and Emerson, 1990; Cacho et al., 2001; Schönfeld, 2001; Geslin et al., 2004). In the literature, this species is often described as typical of low organic carbon areas (Lutze and Coulbourn, 1984; Corliss, 1985, 1991; Corliss and Emerson, 1990; Fontanier et al., 2002).

Quinqueloculina sp. is part of the species found in infralittoral zones (Jorissen, 1987; Redois and Debenay, 1999).

\section{Ecological significance of ostracods}

- Cluster A1: Monoceratina mediterranea and Bythocypris sp.; bathymetry evolution

Monoceratina mediterranea has been found in recent sediments from the Adriatic Sea at water depths $>160 \mathrm{~m}$, (Bonaduce et al., 1975) and its occurrence in core MD01-2472 follows the evolution of the bathymetry in the Holocene. Bythocypris sp. has been described in the Mediterranean Sea as inhabiting deep water settings (Bonaduce et al., 1975; Ertekin and Tunoglu, 2008) at depths greater than $200 \mathrm{~m}$. These two species constituting the cluster A1 are more abundant in B-A interval (12\%) and MIS 1 (Holocene period, 9\%) compared to MIS $2(2 \%)$ and MIS $3(3 \%)$. 
- Cluster A2: Macrocypris sp. and Bathycythere vanstraateni; surface productivity signal

Macrocypris sp. seems to respond to nutrient-rich waters, whereas it preferably inhabits Mg-enriched waters (Cadot et al., 1972; Durazzi, 1977; Wansard, 1999). Its presence might be related to the increasing surface productivity or/and river detrital input (Bassetti et al., 2010). B. vanstraateni is a bathyal species requiring cold, nutrient-rich waters and, possibly, a low sedimentation rate (Alvarez Zarikian et al., 2009)

B. vanstraateni, Macrocypris sp. are very well represented in MIS 2 and MIS 3. They completely disappear in MIS 1 (Fig. 8).

- Cluster A3: Callistocythere sp., Hemicytherura videns and Aurila sp.; downslope transport signal

Aurila sp. belongs to the infralittoral species and is widely distributed in the Mediterranean and along the coast of north-western Europe (Bonaduce et al., 1975). Abundance of Aurila sp. is often related to increased rates of detrital sedimentation (Babinot and Boukli-Hacene, 1998). Callistocythere sp. and $H$. videns also indicate the infralittoral zone (Carbonel, 1980; Ruiz et al., 1997; Abad et al., 2005; El Hmaidi et al., 2010; Nachite et al., 2010). In the Mediterranean Sea, Callistocythere sp. is often observed in sandy-silt bottoms. Based on the depth $(501 \mathrm{~m})$ where the core was taken, this cluster can be use as an indicator of displacement or transport. Aurila sp., Callistocythere sp. and H. videns are well represented in MIS 2 and MIS 3, particularly in Greenland stadials.

- Cluster B1: Cytheropteron alatum and Argilloecia acuminata; poorly oxygenated conditions

Argilloecia acuminata is a deep-water species found in the eastern and western Mediterranean Sea (Bonaduce et al., 1975; Colalongo and Pasini, 1980; Müller, 1894). The genus Argilloecia is known to predominate in organic-rich sediment, and was reported as the most common ostracod living in the oxygen minimum zone of the upper continental slope off southeastern North America (Cronin, 1983). Argilloecia is also an important component of the Pliocene (Cronin et al., 1996) and late Pleistocene (Cronin et al., 1999; Didié and Bauch, 
2000) assemblages from the Mid-Atlantic Ridge and eastern North Atlantic that represent climatic transitions, especially deglacial periods and stadial-interstadial transitions (Yasuhara et al., 2008). Peaks of Argilloecia may indicate low oxygen bottom waters (Alvarez Zarikian et al., 2009). In the Mediterranean Sea, C. alatum and A. acuminata are found in ostracod assemblages corresponding to the early and late Holocene in the Alboran sea (El Hmaidi et al., 2010). In core MD01-2472, A. acuminata and C. alatum are found more abundantly during MIS 3, particularly in Greenland interstadials (up to 60\%), and decrease during MIS 2. In MIS 1, abundance generally ranges between $20 \%$ and $35 \%$, (Fig. 8).

- Cluster B2: Henryhowella sp., Pseudocythere caudata and Paracypris sp.; low energy and low oxygenated environments

Pseudocythere caudata and Henryhowella sp. are bathyal species. Paracypris sp. and Henryhowella sp. are typical of low energy environments (Guernet, 2005). Paracypris sp. can tolerate low oxygen content (Andreu, 1992). During the MIS 3, Paracypris sp., P. caudata and Henryhowella sp. present abundance peaks in correspondence with Greenland interstadials (with percentages between $1 \%$ and 30\%). They greatly increase during Termination I with peak of $50 \%$ at 14,300 y BP (B-A period, Fig. 8).

- Cluster B3: Semicytherura sp., Paradoxostoma sp., Xestoleberis sp. and Loxoconcha levis; downslope transport signal

Semicytherura sp., Xestoleberis sp., Paradoxostoma sp. and L. levis are species found in infralittoral environments, in the Mediterranean Sea (Bonaduce et al., 1975; Hajjaji et al., 1998). These species are more abundant during MIS 2 and MIS 3 with abundance peaks related to cold phases. However, they decrease during the LGM period and their highest percentage is found during the YD period (53\%, Fig 8).

- Cluster B4: Echinocythereis echinata and Krithe spp.; well-oxygenated conditions

Echinocythereis echinata is well known for characterizing nutrient-rich waters (Didié et al., 2002; Bassetti et al., 2010). Krithe spp. are here considered as markers of generally well-oxygenated, cold water environments. Species of Krithe have different depth distributions ranging from $<500$ to $>5000 \mathrm{~m}$ (Rodriguez-Lazaro and Cronin, 1999), but 
previous studies have shown that the genus is mainly associated with cold water masses (Cronin et al., 1999; Ayress et al., 2004; Alvarez Zarikian et al., 2009; Bassetti et al., 2010;). E. echinata and Krithe spp. are abundant in MIS 2 and in MIS 3 (Fig. 8). During MIS 1, Krithe spp. decrease to $<10 \%$ (Fig. 9).

Polycope sp.; low current velocities and lower bottom water oxygenation indicator

Polycope sp. is a swimming ostracod, preferring fine-grained, organic-rich sediments and low current velocities, implying low bottom water oxygenation (Benson et al., 1983; Cronin et al., 1995; Alvarez Zarikian et al., 2009). It is the most abundant ostracod species with percentages up to $70 \%$ in MIS 1 (Fig. 8). Polycope sp. shows a very low correlation with all the other ostracod species and can not be grouped to any of clusters.

\section{References}

Abad, M., Ruiz, F., Pendón, J.G., Ma Luz González-Regalado, Tosquella, J., 2005. Tortonian ostracodes of Southwestern Europe Ostracodes tortoniens du Sud-Ouest de l'Europe. Geobios 38, 563-573

Abu-Zied, R.H., Rohling, E.J., Jorissen, F.J., Fontanier, C., Casford, J.S.L., Cooke, S., 2008. Benthic foraminiferal response to changes in bottom-water oxygenation and organic carbon flux in the eastern Mediterranean during LGM to Recent times. Marine Micropaleontology 67 (1-2), 46-68.

Alvarez Zarikian, C.A., Stepanova, A.Y., Grützner, J., 2009. Glacial-interglacial variability in deep sea ostracod assemblage composition at IODP Site U1314 in the subpolar North Atlantic. Marine Geology 258 (1-4), 69-87.

Alves Martins, M.V., Dragao Gomes, V., 2004. Foraminiferos da margem continental NW iberica. Figueiredo Gomes, C.S., (Eds.), 377 pp.

Ayress, M.A., De Deckker, P., Coles, G.P., 2004. A taxonomic and distributional survey of marine benthonic Ostracoda off Kerguelen and Heard Islands, South Indian Ocean. Journal of Micropalaeontology 23 (1), 15-38.

Andreu, B., 1992. Associations d'ostracodes et paléoécologie du Crétacé (Barrémien à Turonien) le long d'une transversale Agadir-Nador (Maroc). Palaeogeography, Palaeoclimatology, Palaeoecology 99 (3-4), 291-319.

Babinot, J.-F., Boukli-Hacene, S., 1998. Associations d'ostracodes en faciès mixtes de plateforme: l'exemple du messinien de la région nord des tessala (Oranie, Algérie). Revue de Micropaléontologie 41 (1), 3-17.

Bandy, O.L., 1972. Origin and development of Globorotalia (Turborotalia) pachyderma (Ehrenberg). Micropaleontology 18, 294-318.

Barmawidjaja, D.M., Jorissen, F.J., Puskaric, S., Van der Zwaan, G.J., 1992. Microhabitat selection by benthic foraminifera in the Northern Adriatic sea. Journal of Foraminiferal Research 22, 297-317.

Bassetti, M.A., Carbonel, P., Sierro, F.J., Perez-Folgado, M., Jouët, G., Berné, S., 2010. Response of ostracods to abrupt climate changes in the Western Mediterranean (Gulf of Lions) during the last 30 kyr. Marine Micropaleontology 77 (1-2), 1-14.

Bé, A.W.H., Tolderlund, D.S., 1971. Distribution and ecology of living planktonic foraminifera in surface waters of the Atlantic and Indian Oceans. In: Funnel, B.M., 
Riedel, W.R. (Eds.), Micropaleontology of the Oceans. Riedel, Cambridge University Press, London., pp. 105-149.

Bé, A.W.H., Hutson, W.H., 1977. Ecology of planktonic foraminifera and biogeographic patterns of life and fossil assemblages in the Indian Ocean. Micropaleontology 23 (4), 369-414.

Benson, R.H., DelGrosso, R.M., P.L., S., 1983. Newfoundland continental rise and slope. Micropaleontology 29, 430-453.

Bernhard, J., Sen Gupta, B.K., 1999. Foraminifera of oxygen-depleted environments. In: Sen Gupta, B.K.E. (Ed.), Modern Foraminifera. Kluwer Academic Publishers, Kluwer Academic Publishers, pp. 201-216.

Bonaduce, G., Ciampo, G., Masoli, M., 1975. Distribution of Ostracoda in the Adriatic Sea. Pubbl. Staz. Zool. Napoli 40 (1), 1-148.

Cacho, I., Grimalt, J.O., Canals, M., Sbaffi, L., Shackleton, N.J., Schönfeld, J., Zahn, R., 2001. Variability of the western Mediterranean Sea surface temperature during the last 25,000 years and its connection with Northern Hemisphere climatic changes. Paleoceanography 16 (1), 40-52.

Cadot, H.M., Van Schmus, W.R., Kaesler, R.L., 1972. Magnesium in Calcite of Marine Ostracoda. Geological Society of America Bulletin 83 (11), 3519-3522.

Carbonel, P., 1980. Les ostracodes et leur intérêt dans la définition des écosystèmes estuariens et de plate-forme continentale. Essais d'application à des domaines anciens. Bulletin de l'Institut de Géologie du Bassin d'Aquitaine, pp. 1-330

Cifelli, R., 1973. Observation on Globigerina pachyderma (Ehrenberg) and Globigerina incompta Cifelli from the North Atlantic. Journal of Foraminiferal Research 3, 157166.

Colalongo, M.L., Pasini, G., 1980. La ostracofauna plio-pleistocenica della sezione Vrica in Calabria (con considerazioni sul limite Neogene/Quaternario). Bollettino della Societá Paleontologica Italiana 19, 44-126.

Corliss, B.H., 1985. Microhabitats of benthic foraminifera within deep-sea sediments. Nature 314, 435-438.

Corliss, B.H., 1991. Morphology and microhabitat preferences of benthic foraminifera from the Northwest Atlantic Ocean. Marine Micropaleontology 17, 195-236.

Corliss, B.H., Emerson, S., 1990. Distribution of rose bengal stained deep-sea benthic foraminifera from the Nova Scotian continental margin and Gulf of Maine. Deep Sea Research Part A. Oceanographic Research Papers 37 (3), 381-400.

Cronin, T.M., 1983. Bathyal ostracodes from Florida-Hatteras Slope, the straits of Florida and the Blake Plateau. Marine Micropaleontology 8, 89-19.

Cronin, T.M., Holtz, J.T.R., Stein, R., Spielhagen, R., Futterer, D., Wollenburg, J., 1995. Late Quaternary paleoceanography of the Eurasian Basin, Artic Ocean. Paleoceanography $10(2), 259-281$.

Cronin, T.M., Raymo, M.E., Kyle, K.P., 1996. Pliocene (3.2-2.4 Ma) ostracode faunal cycles and deep ocean circulation, North Atlantic Ocean. Geology 24 (8), 695-698.

Cronin, T.M., DeMartino, D.M., Dwyer, G.S., Rodriguez-Lazaro, J., 1999. Deep-sea ostracode species diversity: response to late Quaternary climate change. Marine Micropaleontology 37 (3-4), 231-249.

De Rijk, S., Jorissen, F.J., Rohling, E.J., Troelstra, S.R., 2000. Organic flux control on bathymetric zonation of Mediterranean benthic foraminifera. Marine Micropaleontology 40 (3), 151-166.

De Stigter, H.C., Jorissen, F.J., van der Zwaan, G.J., 1998. Bathymetric distribution and microhabitat partitioning of live (Rose Bengal stained) foraminifera along a shelf to 
bathyal transect in the southern Adriatic Sea. Journal of Foraminiferal Research 28, 40-65.

Didié, C., Bauch, H.A., 2000. Species composition and glacial-interglacial variations in the ostracode fauna of the northeast Atlantic during the past 200,000 years. Marine Micropaleontology 40 (1-2), 105-129.

Didié, C., Bauch, H.A., P. Helmke, J., 2002. Late Quaternary deep-sea ostracodes in the polar and subpolar North Atlantic: paleoecological and paleoenvironmental implications. Palaeogeography, Palaeoclimatology, Palaeoecology 184 (1-2), 195-212.

Durazzi, J.T., 1977. Stable isotopes in the ostracod shell: a preliminary study. Geochimica et Cosmochimica Acta 41 (8), 1168-1170.

El Hmaidi, A., El Moumni, B., Nachite, D., Bekkali, R., Gensous, B., 2010. Distribution et caractéristiques des associations d'ostracodes au Pléistocène supérieur et Holocène au niveau de la marge orientale du détroit de Gibraltar (mer d'Alboran, Maroc). Revue de Micropaléontologie 53 (1), 17-28.

Ertekin, I.K., Tunoglu, C., 2008. Pleistocene-Holocene marine ostracods from Mersin offshore sediments, Turkey, Eastern Mediterranean. Revue de Micropaléontologie 51 (4), 309-326.

Fontanier, C., Jorissen, F.J., Licari, L., Alexandre, A., Anschutz, P., Carbonel, P., 2002. Live benthic foraminiferal faunas from the Bay of Biscay: faunal density, composition, and microhabitats. Deep Sea Research Part I: Oceanographic Research Papers 49 (4), 751785.

Frezza, V., Carboni, M.G., 2009. Distribution of recent foraminiferal assemblages near the Ombrone River mouth (Northern Tyrrhenian Sea, Italy). Revue de Micropaléontologie $52(1), 43-66$.

Geslin, E., Heinz, P., Jorissen, F., Hemleben, C., 2004. Migratory responses of deep-sea benthic foraminifera to variable oxygen conditions: laboratory investigations. Marine Micropaleontology 53 (3-4), 227-243.

Gooday, A.J., 1994. The biology of deep-sea foraminifera: a review of some advances and their applications in paleoceanography. Palaios 9, 14-31.

Guernet, C., 2005. Ostracodes et stratigraphie du néogène et du quaternaire méditerranéens. Revue de Micropaléontologie 48 (2), 83-121.

Hajjaji, M., Bodergat, A.-M., Moissette, P., Prieur, A., Rio, M., 1998. Signification écologique des associations d'ostracodes de la coupe de Kritika (Pliocène supérieur, Rhodes, Grèce). Revue de Micropaléontologie 41 (3), 211-233.

Harloff, J., Mackensen, A., 1997. Recent benthic foraminiferal associations and ecology of the Scotia Sea and Argentine Basin. Marine Micropaleontology 31 (1-2), 1-29.

Haunold, T.G., Baal, C., Piller, W.E., 1997. Benthic foraminiferal associations in the Northern Bay of Safaga, Red Sea, Egypt. Marine Micropaleontology 29 (3-4), 185 210.

Hayward, B.W., Neil, H., Carter, R., Grenfell, H.R., Hayward, J.J., 2002. Factors influencing the distribution patterns of Recent deep-sea benthic foraminifera, east of New Zealand, Southwest Pacific Ocean. Marine Micropaleontology 46, 139-176.

Hemleben, C., Spindler, M., Anderson, O.R., 1989. Modern Plantonic Foraminifera.Springer, New York, 363 pp.

Hess, S., Jorissen, F.J., 2009. Distribution patterns of living benthic foraminifera from Cap Breton canyon, Bay of Biscay: Faunal response to sediment instability. Deep Sea Research Part I: Oceanographic Research Papers 56 (9), 1555-1578.

Johannessen, T., Jansen, E., Flatøy, A., Ravelo, A.C., 1994. The relationship between surface water masses, oceanographic fronts and paleoclimatic proxies in surface sediments of the Greenland, Iceland, Norwegian Seas. NATO ASI Ser. I, 61-86. 
Jorissen, F.J., 1987. The distribution of benthic foraminifera in the Adriatic Sea. Marine Micropaleontology 12, 21-48.

Jorissen, F.J., 1988. Benthic foraminifera from the Adriatic Sea; principles of phenotypic variation. Utrecht Micropaleontology Bulletin 37, 1-176.

Jorissen, F.J., de Stigter, H.C., Vidmark, J.V., 1995. A conceptual model explaining benthic foraminiferal microhabitats. Marine Micropaleontology 26, 3-15.

Jorissen, F.J., Wittling, I., Peypouquet, J.P., Rabouille, C., Relexans, J.C., 1998. Live benthic foraminiferal faunas off Cape Blanc, NW-Africa: Community structure and microhabitats. Deep Sea Research Part I: Oceanographic Research Papers 45 (12), 2157-2188.

Jorissen, F.J., 1999b. Benthic foraminiferal successions across Late Quaternary Mediterranean sapropels. Marine Geology 153 (1-4), 91-101.

Jorissen, F.J., Fontanier, C., Thomas, E., 2007. Chapter Seven Paleoceanographical Proxies Based on Deep-Sea Benthic Foraminiferal Assemblage Characteristics, in: Claude, H.M., Anne De, V. (Eds.), Developments in Marine Geology. Elsevier, pp. 263-325.

Kroon, D., 1991. Distribution of extant planktic foraminiferal assemblages in Red Sea and Northern Indian Ocean surface waters.Rev. Esp. Micropaleontol. 23, 37-74.

Lutze, G.F., 1980. Depth distribution of benthic foraminifera on the continental margin off NW Africa. Meteor Forsch Ergebn C 32, 31-80.

Lutze, G.F., Coulbourn, W.T., 1984. Recent benthic foraminifera from the continental margin of northwest Africa: Community structure and distribution. Marine Micropaleontology $8(5), 361-401$.

Lutze, G.F., Thiel, H., 1989. Epibenthic foraminifera from elevated microhabitats; Cibicidoides wuellerstorfi and Planulina ariminensis. The Journal of Foraminiferal Research 19, 153-158.

Mackensen, A., Fütterer, D.K., Grobe, H., Schmiedl, G., 1993. Benthic foraminiferal assemblages from the eastern South Atlantic Polar Front region between $35^{\circ}$ and $57^{\circ} \mathrm{S}$ : Distribution, ecology and fossilization potential. Marine Micropaleontology 22, 33-69.

Mojtahid, M., Jorissen, F., Lansard, B., Fontanier, C., Bombled, B., Rabouille, C., 2009. Spatial distribution of live benthic foraminifera in the Rhône prodelta: Faunal response to a continental-marine organic matter gradient. Marine Micropaleontology 70 (3-4), 177-200.

Morigi, C., Jorissen, F.J., Gervais, A., Guichard, S., Borsetti, A.M., 2001. Benthic foraminiferal faunas in surface sediments off NW Africa: relationship with organic flux to the ocean floor. Journal of Foraminiferal Research 31 (4), 350-368.

Müller, G.W., 1894. Die Ostracoden des Golfes von Neapel und der angrenzenden Meeresabschnitte. Zoologische Station zu Neapel. Fauna und Flora des Golfes von Neapel. Monographie 31, 1-404.

Nachite, D., Rodríguez-Lázaro, J., Martín-Rubio, M., Pascual, A., Bekkali, R., 2010. Distribution et écologie des associations d'ostracodes récents de l'estuaire de Tahadart (Maroc Nord-Occidental). Revue de Micropaléontologie 53 (1), 3-15.

Parker, F.L., 1958. Eastern Mediterranean foraminifera. Reports of the Swedish Deep Sea Expedition, vol. VIII: Sediment cores from the Mediterranean and the Red Sea, 4, 219-283.

Parker, F.L., 1971. Distribution of planktonic foraminifera in Recent deep-sea sediments. In: Funnell, B.M., Riedel, W.R. (Eds.), The Micropaleontology of the Oceans. Cambridge University Press, Cambridge, pp.289-307.

Rasmussen, T.L., Thomsen, E., Troelstra, S.R., Kuijpers, A., Prins, M.A., 2003. Millennialscale glacial variability versus Holocene stability: changes in planktic and benthic 
foraminifera faunas and ocean circulation in the North Atlantic during the last 60000 years. Marine Micropaleontology 47, 143-176.

Rathburn, A.E., Corliss, B.H., 1994. The ecology of living (stained) deep-sea benthic foraminifera from the Sulu Sea. Paleoceanography 9, 1617-1646.

Redois, F., Debenay, J.-P., 1999. Répartition des foraminifères benthiques actuels sur le plateau continental sénégalais au sud de Dakar. Oceanologica Acta 22 (2), 215-232.

Reynolds, L., Thunell, R.C., 1985. Seasonal succession of planktonic foraminifera in the subpolar North Pacific. Journal of Foraminiferal Research 15 (4), 282-301.

Reynolds, L.A., Thunell, R.C., 1986. Seasonal production and morphologic variation of Neogloboquadrina pachyderma (Ehrenberg) in the Northeast Pacific. Micropaleontology 32, 1-18.

Rodriguez-Lazaro, J., Cronin, T.M., 1999. Quaternary glacial and deglacial Ostracoda in the thermocline of the Little Bahama Bank (NW Atlantic): palaeoceanographic implications. Palaeogeography, Palaeoclimatology, Palaeoecology 152 (3-4), 339-364.

Rogerson, M., Kouwenhoven, T.J., van der Zwaan, G.J., O'Neill, B.J., van der Zwan, C.J., Postma, G., Kleverlaan, K., Tijbosch, H., 2006. Benthic foraminifera of a Miocene canyon and fan. Marine Micropaleontology 60 (4), 295-318.

Ross, C.R., 1984. Hyalinea balthica and its late Quaternary paleoclimatic implications; Strait of Sicily. The Journal of Foraminiferal Research 14 (2), 134-139.

Ruiz, F., González-Regalado, M.L., Muñoz, J.M., 1997. Multivariate analysis applied to total and living fauna: seasonal ecology of recent benthic Ostracoda off the North Cádiz Gulf coast (southwestern Spain). Marine Micropaleontology 31 (3-4), 183-203.

Schmiedl, G., Mackensen, A., 1997. Late Quaternary paleoproductivity and deep water circulation in the eastern South Atlantic Ocean: Evidence from benthic foraminifera. Palaeogeography, Palaeoclimatology, Palaeoecology 130 (1-4), 43-80

Schmiedl, G., de Bovée, F., Buscail, R., Charrière, B., Hemleben, C., Medernach, L., Picon, P., 2000. Trophic control of benthic foraminiferal abundance and microhabitat in the bathyal Gulf of Lions, western Mediterranean Sea. Marine Micropaleontology 40, 167-188.

Schmiedl, G., Mitschele, A., Beck, S., Emeis, K.-C., Hemleben, C., Schulz, H., Sperling, M., Weldeab, S., 2003. Benthic foraminiferal record of ecosystem variability in the eastern Mediterranean Sea during times of sapropel S5 and S6 deposition. Palaeogeography, Palaeoclimatology, Palaeoecology 190 (0), 139-164

Schönfeld, J., 2001. Benthic foraminifera and pore-water oxygen profiles. A re-assessment of species boundary conditions at the western Iberian Margin. Journal of Foraminiferal Research 31, 86-107.

Serrano, F., Guerra-Merchán, A., 2012. Sea-surface temperature for left-coiling Neogloboquadrina populations inhabiting the westernmost Mediterranean in the middle Pleistocene and the Pleistocene-Pliocene transition. Geobios 45 (2), 231-240.

Sierro, F.J., Hodell, D.A., Curtis, J.H., Flores, J.A., Reguera, I., Colmenero-Hidalgo, E. Barcena, M.A., Grimalt, J.O., Cacho, I., Frigola, J., Canals, M., 2005. Impact of iceberg melting on Mediterranean thermohaline circulation during Heinrich events Paleoceanography 20 (PA201).

Spindler, M., 1990. A comparison of Arctic and Antarctic sea ice and the effects of different properties on sea ice biota. In: Bleil, U., Thiede, J. (Eds.), Geological History of the Polar Oceans: Arctic versus Antarctic. Kluwer, Amsterdam, pp. 173-186.

van Morkhoven, F.P.C.M., Berggren, W.A., Edwards, A.S., 1986. Cenozoic cosmopolithan deep-water benthic foraminifera. Bulletin des Centres de Recherches ExplorationProduction Elf-Aquitaine, 421 p. 
Wansard, G., 1999. La géochimie des éléments en traces dans la calcite des ostracodes: Principes, limites et perspectives de la méthode pour une reconstitution quantifiée des paléoenvironnements. Geobios 32 (6), 928-933.

Yasuhara, M., Cronin, T.M., deMenocal, P.B., Okahashi, H., Linsley, B.K., 2008. Abrupt climate change and collapse of deep-sea ecosystems. Proceedings of the National Academy of Sciences 105 (5). 